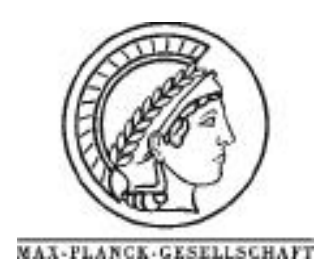

\title{
Redox Behavior of Copper Oxide /Zinc Oxide Catalysts in the Steam Reforming of Methanol studied by in situ X-ray Diffraction and Absorption Spectroscopy
}

\author{
M.M. Günter, T. Ressler*, R.E. Jentoft and B. Bems
}

Department of Inorganic Chemistry, Fritz-Haber-Institute of the MPG, Faradayweg 4-6, 14195 Berlin, Germany

* Corresponding author: e-mail ressler@fhi-berlin.mpg.de, phone +49 308413 3192, fax +49 3084134401

Submitted to Journal of Catalysis

\begin{abstract}
The bulk structure of copper in various binary $\mathrm{Cu} / \mathrm{ZnO}$ catalysts for steam reforming of methanol under activation and working conditions is studied by in situ X-ray diffraction (XRD) and X-ray absorption spectroscopy (XAS). The evolution of bulk phases from CuO/ZnO precursors during activation with hydrogen was studied using temperature programmed reduction (TPR) (448-523 K, 2 vol-\% $\mathrm{H}_{2}$ with and without water vapor). With decreasing copper content the onset of reduction is shifted from $473 \mathrm{~K}$ (pure $\mathrm{CuO})$ to $443 \mathrm{~K}(40 \mathrm{~mol}-\% \mathrm{Cu})$ accompanied by a decrease in $\mathrm{Cu}$ crystallite sizes (from $210 \AA$ to $40 \AA$ ). Using time-resolved in situ XANES measurements at the $\mathrm{Cu} \mathrm{K}$ edge during TPR experiments the degree of reduction was monitored. It is shown that $\mathrm{Cu}(\mathrm{I})$ oxide forms prior to $\mathrm{Cu}$. Adding oxygen to the feed gas leads to the formation of a mixture of $\mathrm{Cu}(\mathrm{II})$ and $\mathrm{Cu}(\mathrm{I})$ oxide accompanied by a complete loss of activity. After switching back to steam reforming conditions a higher activity is attained while the catalyst shows an increased $\mathrm{Cu}$ crystallite size (up to $40 \%$ ). EXAFS measurements at the $\mathrm{Cu} \mathrm{K}$ and the $\mathrm{Zn} \mathrm{K}$ edge indicate a structural disorder of the $\mathrm{Cu}$ particles in the medium range order based on increasing Debye-Waller factors for higher $\mathrm{Cu}$ - $\mathrm{Cu}$ shells. Furthermore, the dissolution of $\mathrm{Zn}$ atoms (up to $\sim 4 \mathrm{~mol}-\%$ ) in the copper lattice is detected. Upon oxidation/reduction cycles activity is increased, the disorder in the copper particles increases, and $\mathrm{Zn}$ segregates out of the copper bulk. A structural model is proposed which ascribes the enhanced activity to structurally disordered (strained) copper particles due to an improved interface interaction with $\mathrm{ZnO}$.
\end{abstract}

Keywords: $\mathrm{Cu} / \mathrm{ZnO}$ catalysts, methanol-steam reforming, temperature programmed reduction, $\mathrm{XRD}, \mathrm{XANES}$, in situ, phase evolution, structure, selectivity, activity, XAFS

\section{Introduction}

$\mathrm{Cu} / \mathrm{ZnO}$ catalysts can be used to produce hydrogen by steam reforming of methanol with high selectivity and activity $(1,2)$. Thus, methanol often is considered as an alternative "automotive" fuel and could serve as a potential hydrogen source for fuel cell applications (3). Current efforts are dedicated to the minimization of selectivity to $\mathrm{CO}$ which acts as a poison in fuel cell applications (4). The steam reforming reaction $\left(\mathrm{CH}_{3} \mathrm{OH}+\mathrm{H}_{2} \mathrm{O} ? \mathrm{CO}_{2}+3 \mathrm{H}_{2}\right)$ can be regarded as the reversed methanol synthesis reaction. However, a detailed reaction mechanism is still under debate $(5,6,7)$. In a kinetic model by Peppley et al. it is assumed that different active phases are responsible for the methanol decomposition, methanolsteam reforming, and the water-gas shift reaction (8).

The $\mathrm{Cu} / \mathrm{ZnO}$ system has been studied extensively after reduction and under working conditions of methanol synthesis $(9,10,11$ and cited references therein). However, the active $\mathrm{Cu}$ phase for methanol reforming is not fully elucidated yet. Previously, differences in the reduction kinetics of $\mathrm{CuO} / \mathrm{ZnO}$ were mainly studied by conventional temperature programmed reduction (TPR) methods $(12,13)$. However, these methods do not measure the structural evolution of the catalyst during reduction $(e . g$. evolution of different bulk phases). Fierro et. al. studied the reduction of $\mathrm{CuO} / \mathrm{ZnO}$ with different $\mathrm{Cu} / \mathrm{Zn}$ ratios and found a 
promoting effect of $\mathrm{ZnO}$ on the reducibility of $\mathrm{CuO}(14)$. The reduction kinetics of copper oxide were determined by thermogravimetric methods $(15,16)$ which afforded sigmoidal curves indicating a nucleation growth mechanism. Structural investigations of the copper phase under reduction conditions based on XRD have been reported by Himelfarb et al. (17) and Vong et al. (18). Himelfarb et al. and Porta et al. (19) described an intermediary $\mathrm{Cu}_{2} \mathrm{O}$ phase, whereas this phase was not observed by Vong et al. However, the detection of $\mathrm{Cu}_{2} \mathrm{O}$ is based on ex situ investigations which may not represent the "real" state of the $\mathrm{Cu}$ phase under reduction conditions. Als-Nielsen et. al. reported on an in situ detection of $\mathrm{Cu}_{2} \mathrm{O}$ by time-resolved QEXAFS without further analyzing the growth kinetics of this phase (20). Reitz et. al. (21) observed $\mathrm{Cu}^{+}$as a transient species in the reduction of $\mathrm{CuO} / \mathrm{ZnO}$ catalysts by time-resolved XANES. FernándezGarcía et al. reported on the basis of a statistical analysis of TPR data of $\mathrm{Cu} / \mathrm{Al}_{2} \mathrm{O}_{3}$ that the reduction process of copper aluminate proceeds via a two step mechanism (22). Recently, Grunwaldt et al. observed dynamical changes of the $\mathrm{Cu}$ coordination number upon changes in the gas phase reduction potential by in situ EXAFS during methanol synthesis (23).

Regarding the active state of $\mathrm{Cu} / \mathrm{ZnO}$ catalysts, different authors claim that the ratio of $\mathrm{Cu} / \mathrm{Cu}^{+}$governs the methanol conversion (24). This interpretation is closely related to the model of the active $\mathrm{Cu} / \mathrm{ZnO}$ phase in methanol synthesis developed by Klier (25). Peppley et al. on the basis of a surface mechanism for methanol steam reforming proposed in a recent publication that the nature of the active sites differs according to their function (8), but no structural details are provided. The effects of preparation condition of precursors for $\mathrm{Cu} / \mathrm{ZnO}$ catalysts upon precursors phases, surface structure and catalytic activity for steam reforming of methanol has been investigated by Shen et. al. (26).

In this study we used two complementary bulk techniques, in situ X-ray diffraction and Xray absorption spectroscopy to elucidate bulk structural changes of $\mathrm{Cu}$ in $\mathrm{Cu} / \mathrm{ZnO}$ systems during activation and under methanol steam reforming conditions. First, the evolution of bulk phases during activation of the catalyst (i. e. reduction in hydrogen with ('wet') and without ('dry') additional water vapor) was investigated. Secondly, correlations between the bulk structure of $\mathrm{Cu}$ on $\mathrm{ZnO}$ and activity or selectivity in the steam reforming of methanol are presented.

\section{Experimental Procedure}

$\mathrm{CuO} / \mathrm{ZnO}$ preparation and characterization

$\mathrm{CuO} / \mathrm{ZnO}$ precursors were prepared according to the coprecipitation method, both at a constant $p H$ of 7.0 and with decreasing $p H$, from metal nitrate and sodium carbonate solutions. Binary hydroxycarbonate precursors of a systematic series with varying $\mathrm{Cu} / \mathrm{Zn}$ molar ratios were obtained and are denoted in the following according to their nominal $\mathrm{Cu} / \mathrm{Zn}$ atomic ratio $(100 / 0,90 / 10,80 / 20,70 / 30$, $60 / 40,50 / 50,40 / 60,30 / 70,20 / 80,10 / 90,0 / 100)$.

Table 1 Chemical composition and characterization of calcined $\mathrm{CuO} / \mathrm{ZnO}$ precursors and reduced $\mathrm{Cu} / \mathrm{ZnO}$. Calcination conditions: $600 \mathrm{~K}$ for $3 \mathrm{~h}$ in stagnant air. Onset of reduction during TPR and the corresponding copper crystallites sizes after reduction are measured by in situ XRD. The reduction was performed under both 'dry' and 'wet' reducing conditions.

\begin{tabular}{|c|c|c|c|c|c|c|c|c|c|c|}
\hline \multirow[t]{3}{*}{$\begin{array}{l}\text { Sample } \\
\text { name }\end{array}$} & \multirow{3}{*}{$\begin{array}{c}\text { nominal } \\
\mathrm{Cu} / \mathrm{Zn} \text { ratio } \\
\text { [at.\%] }\end{array}$} & \multirow{3}{*}{$\begin{array}{c}\text { chemical } \\
\text { compositio }^{\mathrm{a}} \\
\mathrm{Cu} / \mathrm{Zn}[\text { at.\%] }\end{array}$} & \multirow[t]{3}{*}{$\begin{array}{l}p H \text { during } \\
\text { precipitation }\end{array}$} & \multirow{3}{*}{$\begin{array}{c}\mathrm{CuO} \\
\text { crystallite } \\
\mathrm{b} \text { size }[\AA]\end{array}$} & \multirow{3}{*}{$\begin{array}{c}\mathrm{ZnO} \\
\text { crystallite } \\
\text { size }[\AA]\end{array}$} & \multirow[t]{3}{*}{$\begin{array}{c}\mathrm{S}_{\mathrm{BET}} \\
{\left[\mathrm{m}^{2} / \mathrm{g}\right]}\end{array}$} & \multicolumn{2}{|c|}{$\begin{array}{c}\text { onset of } \\
\text { reduction }[\mathrm{K}]\end{array}$} & \multicolumn{2}{|c|}{$\begin{array}{c}\text { Cu crystallite } \\
\operatorname{size}^{\mathrm{e}}[\AA]\end{array}$} \\
\hline & & & & & & & \multicolumn{4}{|c|}{ reduction conditions } \\
\hline & & & & & & & 'dry' ${ }^{f}$ & 'wet'g & 'dry' & 'wet' \\
\hline $\mathrm{C} 100 / 0$ & $100 / 0$ & $100 / 0$ & $\begin{array}{c}\text { constant } \\
(7.0)\end{array}$ & 137 & - & 33 & 463 & 468 & 215 & 190 \\
\hline $\mathrm{C} 90 / 10$ & $90 / 10$ & $91 / 09$ & $\begin{array}{c}\text { constant } \\
(7.0)\end{array}$ & 59 & $-\mathrm{c}$ & 70 & 443 & 458 & 112 & 127 \\
\hline $\mathrm{C} 80 / 20$ & $80 / 20$ & $82 / 18$ & $\begin{array}{c}\text { constant } \\
(7.0)\end{array}$ & 41 & $-\mathrm{c}$ & 76 & 473 & 443 & 90 & 92 \\
\hline $\mathrm{C} 70 / 30$ & $70 / 30$ & $73 / 27$ & $\begin{array}{c}\text { constant } \\
(7.0)\end{array}$ & 40 & 40 & 76 & 438 & 458 & 68 & 70 \\
\hline $\mathrm{C} 60 / 40$ & $60 / 40$ & $63 / 37$ & $\begin{array}{l}\text { constant } \\
(7.0)\end{array}$ & 46 & 43 & 82 & 443 & 453 & 77 & 78 \\
\hline $\mathrm{C} 50 / 50$ & $50 / 50$ & $53 / 47$ & $\begin{array}{l}\text { constant } \\
(7.0)\end{array}$ & 46 & 43 & 89 & 463 & 453 & 50 & 58 \\
\hline $\mathrm{C} 40 / 60$ & $40 / 60$ & $45 / 55$ & $\begin{array}{c}\text { constant } \\
(7.0)\end{array}$ & 45 & 46 & 96 & 443 & 448 & 42 & 47 \\
\hline $\mathrm{D} 100 / 0$ & $100 / 0$ & $100 / 0$ & decreasing & 125 & - & 45 & 458 & 468 & 148 & 171 \\
\hline D70/30 & $70 / 30$ & $74 / 26$ & decreasing & 100 & 71 & 83 & 448 & $463 \pm 5^{\mathrm{d}}$ & 81 & 79 \\
\hline D60/40 & $60 / 40$ & $66 / 34$ & decreasing & 78 & 66 & 89 & 448 & 453 & 101 & 108 \\
\hline D50/50 & $50 / 50$ & $56 / 44$ & decreasing & 58 & 64 & 96 & 448 & 468 & 45 & 52 \\
\hline D $40 / 60$ & $40 / 60$ & $46 / 54$ & decreasing & 60 & 77 & 99 & 443 & 453 & 38 & 40 \\
\hline
\end{tabular}

${ }^{a} \mathrm{Cu} / \mathrm{Zn}$ ratio determined by X-ray absorption, ${ }^{\mathrm{b}}$ calculated using the Scherrer equation for $\mathrm{CuO}(111)$ and $\mathrm{ZnO}(100)$

${ }^{\mathrm{c}}$ not determined because of poor crystallinity, ${ }^{\mathrm{d}}$ reproduced in 3 measurements, ${ }^{\mathrm{e}}$ determined at the end of the TPR run at $523 \mathrm{~K}$

${ }^{f}$ reduction performed in $\sim 2$ vol- $\% \mathrm{H}_{2},{ }^{g}$ reduction performed in $\sim 2.5$ vol- $\% \mathrm{H}_{2}$ and 3 vol- $\% \mathrm{H}_{2} \mathrm{O}$ 
Calcination of the hydroxycarbonate precursors at $600 \mathrm{~K}$ for $3 \mathrm{~h}$ in a muffle furnace in air afforded mixed $\mathrm{CuO} / \mathrm{ZnO}$ systems. More preparative details are given elsewhere (27).

Specific surface areas were calculated by applying the BET method to the nitrogen isotherms obtained at liquid nitrogen temperature on samples outgassed at $423 \mathrm{~K}$ using a Quantasorp jr. (Quantachrom) adsorption instrument.

The sample nomenclature including the $p H$ of the preparation and characterization of the calcined precursor with respect to $\mathrm{CuO}$ and $\mathrm{ZnO}$ crystallite size and the BET surface area is given in Table 1.

\section{In situ XRD}

The in situ XRD experiments were conducted using a STOE STADIP P diffractometer (Cu K? radiation) in the Bragg Brentano scattering geometry equipped with a secondary monochromator and a scintillation counter operated in the stepping mode. The in situ cell consisted of a Bühler $H D K S 1$ high temperature diffraction chamber mounted onto the goniometer (28). In addition to a gas feed system for $\mathrm{He}, \mathrm{O}_{2}$, and $\mathrm{H}_{2}$ as described in ref. (28), $\mathrm{H}_{2} \mathrm{O}$ and $\mathrm{MeOH}$ were introduced by saturation of $\mathrm{He}$ with the respective liquids. Typically, $12 \mathrm{mg}$ of the catalyst sample were used. Prior to any experiment the reactor was purged with He. Reduction of the precursors was performed in situ following a temperature program and in either 2 vol\% $\mathrm{H}_{2}$ (denoted in the following as 'dry' reduction) or in 2.5 vol$\% \mathrm{H}_{2}$ and 3 vol\% $\mathrm{H}_{2} \mathrm{O}$ ('wet' reduction) both in a He-flow of $100 \mathrm{ml} / \mathrm{min}$. During precursor reduction and at temperatures between $433 \mathrm{~K}$ and $523 \mathrm{~K}$ an XRD pattern was recorded every $5 \mathrm{~K}$ at a constant temperature while applying a temperature ramp between every measurement resulting in an effective temperature ramp of $0.5 \mathrm{~K} / \mathrm{min}$. Thus, the uncertainty in on-set temperatures of reduction is $5 \mathrm{~K}$. For the measurements during temperature programmed reduction a counting time of $2 \mathrm{~s} / \mathrm{step}$ and a step width of $0.04^{\circ} 2$ ? was chosen for an interval of $41-$ $46^{\circ}$ 2?. The gas phase over the sample was analyzed quantitatively on-line with a Balzers Prisma 200 quadrupole mass spectrometer .

The full width at half maximum (FWHM) and integrated intensity of XRD-lines were determined by fitting pseudo Voigt (fixed Gauss contribution) and Lorentz. profile functions (more appropriate for strongly broadened profiles) to the $\mathrm{Cu}$ (111) peak. The Scherrer formula was used to estimate the crystallite size on the basis of the FWHM without taking other broadening effects and correction for instrumental broadening into account (29). Calculation of theoretical X-ray powder patterns and lattice constant refinements were done using the software PowderCell v2.2 (30).

\section{In situ X-ray absorption spectroscopy}

The in situ XAS experiments were performed at beam line $\mathrm{X} 1$ at the Hamburger Synchrotron Radiation Laboratory, HASYLAB, using a $\mathrm{Si}(111)$ double crystal monochromator. The storage ring was operated at $3.6 \mathrm{GeV}$ with injection currents of $150 \mathrm{~mA}$.

The in situ XAS experiments were carried out in the transmission mode in a flow-reactor at atmospheric pressures 31 ). $\mathrm{CuO} / \mathrm{ZnO}$-samples prepared according to both preparation methods were investigated (constant $\mathrm{pH}$ samples $\mathrm{C} 70 / 30, \mathrm{C} 60 / 40, \mathrm{C} 40 / 60, \mathrm{C} 30 / 70, \mathrm{C} 10 / 90$ and decreasing $p H$ samples D70/30, D60/40, D40/60). The samples were mixed with boron nitride (mass ratio $\mathrm{CuO} / \mathrm{ZnO}: \mathrm{BN}=1: 6)$ and $45 \mathrm{mg}$ of the mixture was pressed with a force of one ton into a $5 \mathrm{~mm}$ in diameter pellet. The absorption jump at the $\mathrm{Cu} \mathrm{K}$ edge was $\sim 1.5$. XANES spectra were measured in the Quick-EXAFS mode with a time resolution of $15 \mathrm{~s} /$ spectra $(8959-9100 \mathrm{eV})$.

A calibrated mass spectrometer (QMS200 Pfeiffer) permitted a quantitative analysis of the gas phase during the experiments. In situ EXAFS spectra were measured after oxidation and re-reduction to reveal structural changes of the $\mathrm{Cu}$ and $\mathrm{Zn}$ phases present. Temperature programmed reduction (TPR) runs were performed with 2 vol\% $\mathrm{H}_{2}$ (constant $\mathrm{pH}$ samples) and 8 vol-\% $\mathrm{H}_{2}$ (decreasing $p H$ samples) from $448-523 \mathrm{~K}$ with a temperature ramp of $5 \mathrm{~K} / \mathrm{min}$.

\section{XANES and EXAFS data analysis}

The software WinXAS v2.0 (32) was used for an analysis of the time-resolved $\mathrm{Cu} \mathrm{K}$ edge XANES data to reveal qualitative and quantitative information on the copper bulk phases under TPR and steam reforming conditions. Identification of the number of phases was achieved by principal component analysis (PCA) of the experimental XANES spectra. Reference spectra of these phases were then used in a least-square fitting procedure of the time-resolved spectra to determine the fraction of each phase present (33). For the extended absorption fine structure (EXAFS) analysis, a smooth atomic background, $?_{0}(\mathrm{k})$, was obtained using cubic splines. The radial distribution function FT(?(k)) was obtained by Fourier transforming the $\mathrm{k}^{3}$-weighted experimental ?(k) function, multiplied by a Bessel window, into R space. EXAFS data analysis was carried out using theoretical backscattering phases and amplitudes calculated with the ab initio multiple-scattering code FEFF 7 (34). Single scattering and multiple scattering paths in the employed model structures were calculated up to $6 \AA$ for $\mathrm{Cu}$ metal and up to $5 \AA$ for $\mathrm{ZnO}$ with a lower limit of $2.0 \%$ in amplitude with respect to the strongest backscattering path. In addition to the $\mathrm{Zn}-\mathrm{O}$ and $\mathrm{Zn}-\mathrm{Zn}$ distances extra $\mathrm{Zn}-\mathrm{Cu}$ shells were employed assuming $\mathrm{Zn}$ on $\mathrm{Cu}$ sites in fcc $\mathrm{Cu}$ metal. EXAFS fitting and simulation were performed using the standard EXAFS formula (k range from 2.0 to $13 \AA^{-1}$, R range 1.5 to $6.0 \AA$ (35). Structural parameters that are determined by a leastsquares EXAFS fit to experimental spectra are (i) one $\mathrm{E}_{0}$ shift for all scattering paths in the $\mathrm{Cu}$ bulk structure, (ii) Debye-Waller factors for single-scattering paths, (iii) single scattering shell distances, $\mathrm{Ri}$, and (iv) a third cumulant (36) to account for slight deviations from a Gaussian pair distribution function. Coordination numbers $(\mathrm{CN})$ were 
kept constant in the refinement. This restriction was necessary to reduce the number of free running parameter $\left(\mathrm{N}_{\text {free }}\right)$ to much less than the number of independent parameters $\left(\mathrm{N}_{\text {ind }}\right)$ in the experimental data used. EXAFS refinements reported here were carried out in $\mathrm{R}$ space to fit the magnitude and imaginary part of a Fourier transformed $\mathrm{k}^{3}$-weighted experimental ? $(\mathrm{k})$. More details about the XAFS fitting procedure employed can be found in reference (37).

\section{In-situ methanol steam reforming activity}

The catalytic activity of the $\mathrm{Cu} / \mathrm{ZnO}$ samples for steam reforming of methanol was determined at atmospheric pressure and $523 \mathrm{~K}$ using saturators for methanol and water at room temperature. After temperature programmed reduction and cooling to $298 \mathrm{~K}$, the binary $\mathrm{Cu} / \mathrm{ZnO}$ samples were exposed to $\mathrm{MeOH} / \mathrm{H}_{2} \mathrm{O}$ vapor in a ratio of $4 / 1$ $\left(\mathrm{c}(\mathrm{MeOH}) \sim 6\right.$ vol\%, $\mathrm{c}\left(\mathrm{H}_{2} \mathrm{O}\right) \sim 1.5$ vol\%) diluted in $\mathrm{He}$; total flow through the XRD cell was $120 \mathrm{ml} / \mathrm{min}$, and through the XAS cell was $25 \mathrm{ml} / \mathrm{min}$. Next, the temperature was increased from RT to $523 \mathrm{~K}$ at $20 \mathrm{~K} / \mathrm{min}$. Reactants and products $\left(\mathrm{MeOH}, \mathrm{H}_{2} \mathrm{O}, \mathrm{H}_{2}, \mathrm{CO}_{2}\right.$, and $\left.\mathrm{CO}\right)$ were quantitatively monitored with a mass spectrometer (time resolution $12 \mathrm{~s}$ per scan). In order to measure changes in the phase composition during oxidation and reduction cycles, oxygen was added to the feed at $(523 \mathrm{~K})$ while the reaction was progressing $\left(22 \mathrm{vol} \% \mathrm{O}_{2}\right.$ for intervals of 100 min (in situ $\mathrm{XRD}$ ) and 15 vol $\% \mathrm{O}_{2}$ for $10 \mathrm{~min}$ (in situ $\mathrm{XAS})$ ).

In the following, selectivity refers to $\mathrm{CO}_{2}$ instead of $\mathrm{H}_{2}$ because reactions other than the desired steam reforming produce hydrogen as well (i.e. decomposition to carbon monoxide and hydrogen, and dehydrogenation to formaldehyde and hydrogen). In addition, the water-gas shift reaction may also produce hydrogen. An error is introduced by not differentiating the $\mathrm{CO}_{2}$ stemming from the water-gas shift reaction. However, this reaction occurs to a much smaller extent than the steam reforming reaction. In order to express the hydrogen production activity in terms of a turnover frequency $(i$.e. number of product molecules of hydrogen formed per surface atom $\mathrm{Cu}$ per second) the number of exposed $\mathrm{Cu}$ surface atoms must be estimated. The number of surface atoms was calculated for the $\mathrm{Cu}$ surface area using a mean surface atom density of $1.47 \cdot 10^{19} \mathrm{~m}^{-2}$ (38). The copper surface area was determined using the XRD crystallite size and assuming a spherical copper crystallite shape. The assumption of spherical copper particles is based on crystallite sizes estimated from the $\mathrm{Cu}$ (200) peak for samples with high copper concentration (> $60 \mathrm{~mol} \% \mathrm{Cu}$ ) which yielded similar values as that derived from the $\mathrm{Cu}$ (111) peak. We have previously shown that the $\mathrm{Cu}$ surface area thus determined agrees well with the surface area based on chemical titration with $\mathrm{N}_{2} \mathrm{O}$ (39).

\section{Results}

\section{I) In situ XRD}

a) Reduction of the $\mathrm{CuO} / \mathrm{ZnO}$ precursor

Structural changes of the $\mathrm{CuO} / \mathrm{ZnO}$ system were monitored by in situ XRD during temperature programmed reduction (TPR). The evolution of the intensity of the $\mathrm{Cu}$ (111) line afforded the onset and extent of reduction while the evolution of the crystallite size was obtained from the line width. In Fig. 1 the normalized $\mathrm{H}_{2}$ and $\mathrm{H}_{2} \mathrm{O}$ MS signals are correlated to the intensity evolution of the $\mathrm{Cu}$ (111) peak during TPR of the sample D70/30 in the range from $433 \mathrm{~K}$ to $523 \mathrm{~K}$ in 2 vol-\% hydrogen. It can be seen that the uptake of $\mathrm{H}_{2}$ coincides with the evolution of $\mathrm{H}_{2} \mathrm{O}$. The increase in the intensity of the $\mathrm{Cu}$ (111) peak indicates the growth of $\mathrm{Cu}$ crystallites. Because $\mathrm{Cu}$ particles large enough to be detected by XRD need to form, the onset of the evolution of the $\mathrm{Cu}$ (111) line is delayed with respect to the hydrogen uptake and the evolution of water.

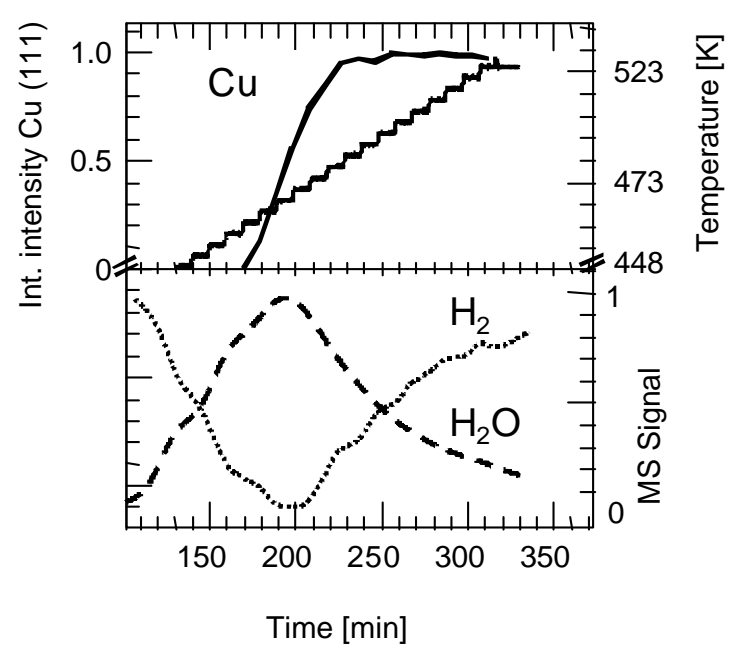

Fig. 1 Evolution of integrated intensity of the $\mathrm{Cu}$ (111) peak and normalized mass spectrometer signals of $\mathrm{H}_{2} \mathrm{O}$ and $\mathrm{H}_{2}$ during TPR of $\mathrm{CuO} / \mathrm{ZnO}$ sample (D70/30) in 2 vol-\% hydrogen measured by in situ XRD. Measuring time 7 $\mathrm{min} / \mathrm{scan}$ with an effective temperature ramp of $0.5 \mathrm{~K} / \mathrm{min}$.

Results of the TPR of all samples are summarized in Table 1. In most cases the onset temperature of 'wet' reduction was about $10 \mathrm{~K}$ higher than the onset temperature of 'dry' reduction. For the constant $p H$ preparation and 'wet' reduction conditions decreasing copper content leads to a lower onset of reduction temperature; from $468 \mathrm{~K}$ (pure $\mathrm{CuO}$, sample $\mathrm{C} 100 / 0$ ) to $448 \mathrm{~K}$ (sample $\mathrm{C} 40 / 60$ ), with sample $\mathrm{C} 80 / 20$ being an exception to this trend. For the decreasing $p H$ samples a similar trend of decreasing onset temperature with decreasing $\mathrm{Cu}$ content is apparent for both 'dry' and 'wet' reduction conditions with sample D50/50 under 'wet' reduction conditions being an exception to this trend. No similar trend is apparent for the samples from the constant $p H$ preparation under 'dry' reduction conditions. In addition, in most cases, 'wet' reduction leads to an increase in $\mathrm{Cu}$ crystallite size with 
respect to that of 'dry' reduction (average increase $\sim 4 \AA$ ). With increasing $\mathrm{Zn}$ content the $\mathrm{Cu} / \mathrm{ZnO}$ samples exhibited a decreasing $\mathrm{Cu}$ crystallite size. The exceptions to the trend of decreasing $\mathrm{Cu}$ particle size with increasing $\mathrm{Zn}$ content are the $60 / 40$ samples.

The evolution of the $\mathrm{Cu}$ crystallite size during TPR is shown in Fig. 2 as a function of the temperature. The $\mathrm{Cu}$ crystallite size appears to increase linearly with time (applying an effective temperature ramp of 0.5 $\mathrm{K} / \mathrm{min}$ ). For samples with lower $\mathrm{Cu}$-concentrations the difference in crystallite size for 'wet' and 'dry' reduced samples is much less pronounced than for $\mathrm{Cu}$-rich samples.

(a)

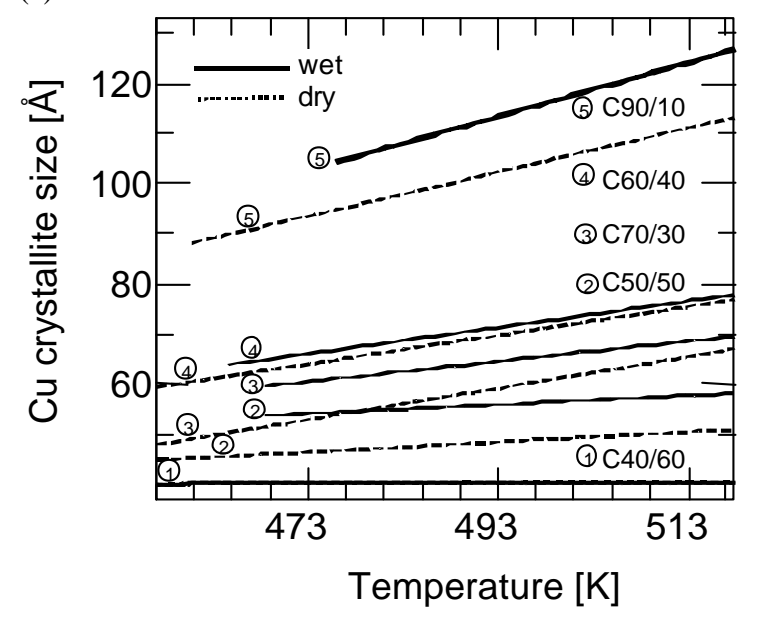

(b)

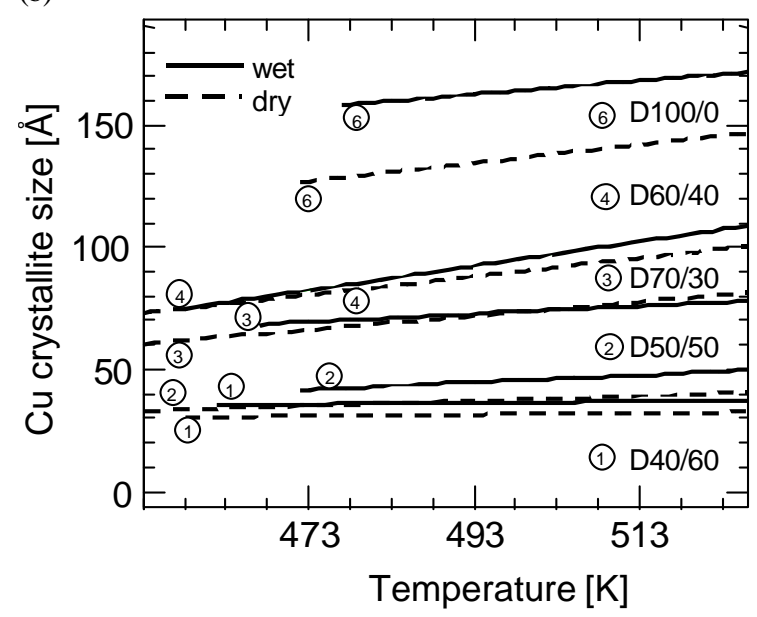

Fig. 2 Evolution of $\mathrm{Cu}$ crystallite size during TPR for samples with different $\mathrm{Cu} / \mathrm{Zn}$ ratios measured both in 3 vol $\% \mathrm{H}_{2}$ ('dry') and 2.5 vol\% $\mathrm{H}_{2}+3$ vol $\% \mathrm{H}_{2} \mathrm{O}$ ('wet') in $100 \mathrm{ml} / \mathrm{min} \mathrm{He}$ for both sets of sample preparations: (a) constant $p H$ preparation, (b) decreasing $p H$ preparation. The temperature was raised with an effective temperature ramp of $0.5 \mathrm{~K} / \mathrm{min}$.

\section{b) Steam reforming of methanol}

The characteristics of the catalytic activity of $\mathrm{Cu} / \mathrm{ZnO}$ catalysts obtained from both preparation batches and reduction procedures ('dry' and 'wet') are summarized in Table 2. Highest conversion (38\%) is obtained for the 'wet' reduced sample D70/30, whereas the 'wet' reduced copper rich sample D100/0 exhibits the lowest conversion. Similarly, the selectivity shows a strong dependence on the composition and reduction conditions and ranges from $79 \%$ ('wet' C60/40) to $16 \%$ ('dry' C90/10). The 'wet' reduced samples C60/40, C50/50, C40/60, and D60/40, D50/50, D40/60 show the same sequence in selectivity (i.e. $\mathrm{S}_{\mathrm{CO}_{2}}$, $60 / 40>\mathrm{S}_{\mathrm{CO}_{2}, 50 / 50}>\mathrm{S}_{\mathrm{CO}_{2}, 40 / 60}$ ) with similar absolute values (see Table 2). While selectivity to $\mathrm{CO}_{2}$ is a function of conversion for all samples, at the same level of conversion the 'wet' reduced samples exhibit an enhanced selectivity compared to that of the 'dry' reduced samples. Selectivities of the 'dry' reduced samples are between 10 and $40 \%$ lower than those of the 'wet' reduced samples. Highest selectivities to $\mathrm{CO}_{2}$ of $\sim 80 \%$ at $\sim 20 \%$ conversion are obtained for the 'wet' reduced samples C70/30 and C60/40 (see Table 2).

The in situ XRD investigations allowed calculation of the $\mathrm{Cu}$ crystallite sizes of operating catalysts which can be used to estimate copper surface areas. Hence, it is possible to detect influences of the $\mathrm{Cu}$ crystallite size (and metal surface area) on the activity without transferring the sample for ex situ measurements.

The $\mathrm{Cu}$ crystallite sizes measured during the steam reforming of methanol, and determined from the $\mathrm{Cu}$ (111) line width, are presented in Table 2. It can be seen by comparison with the crystallite sizes presented in Table 1, measured at the end of the precursor reduction, that during reaction the crystallite sizes increase. Furthermore, the same relationship of decreasing crystallite sizes with decreasing $\mathrm{Cu}$ content is obtained; however, in some cases the initially larger 'wet' reduced crystallites do not increase in size as much as the 'dry' reduced samples and so during reaction exhibit a smaller crystallite size (e.g. samples C80/20, C60/40, C70/30) than the 'dry' reduced samples.

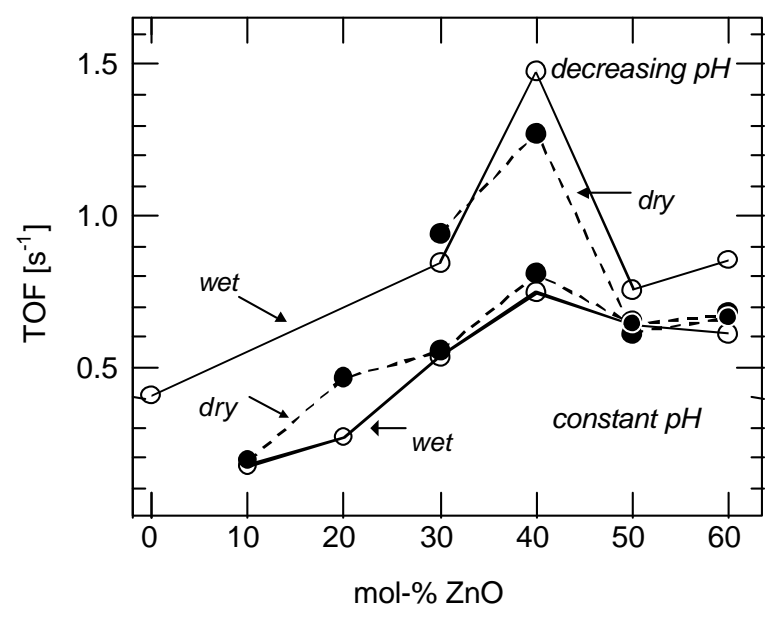

Fig. 3 Initial turn-over-frequency (TOF) for hydrogen production as a function of $\mathrm{ZnO}$-content for catalysts prepared according to the decreasing or the constant $p H$ method (both under 'dry' and 'wet' reduction conditions). Reaction conditions: $\mathrm{MeOH} / \mathrm{H}_{2} \mathrm{O}=4 / 1, \mathrm{p}=101 \mathrm{kPa}$, total flow $\sim 140 \mathrm{ml} / \mathrm{min}$. 
Table 2 Initial methanol steam reforming catalytic activity data (conversion of methanol, selectivity to $\mathrm{CO}_{2}$, hydrogen production rate) and corresponding $\mathrm{Cu}$ crystallite size determined by in situ XRD. Reaction conditions: $\mathrm{MeOH} / \mathrm{H}_{2} \mathrm{O}=4 / 1, \mathrm{p}=$ $101 \mathrm{kPa}$, total flow $\sim 140 \mathrm{ml} / \mathrm{min}$.

\begin{tabular}{|c|c|c|c|c|c|c|c|}
\hline Sample & $\begin{array}{l}\text { Reduction } \\
\text { conditions }\end{array}$ & $\begin{array}{c}\mathrm{Cu} \\
\text { crystallite } \\
\text { size }[\AA]\end{array}$ & $\begin{array}{c}\text { Conversion of } \\
\mathrm{MeOH}, \\
\mathrm{X}_{\mathrm{MeOH}}[\%]\end{array}$ & $\begin{array}{c}\text { Selectivity to } \\
\mathrm{CO}_{2}, \mathrm{~S}_{\mathrm{CO} 2} \\
{[\%]}\end{array}$ & $\begin{array}{c}\text { Hydrogen } \\
\text { production rate, } \mathrm{r}_{\mathrm{H} 2} \\
{\left[\mu \mathrm{molH}_{2} \cdot \mathrm{g}_{\mathrm{cat}}{ }^{-1} \cdot \mathrm{s}^{-1}\right]}\end{array}$ & $\begin{array}{c}\text { Cu Surface } \\
\text { area }^{\mathrm{a}} \mathrm{S}_{\mathrm{Cu}(\mathrm{XRD})} \\
\quad\left[\mathrm{m}^{2} \cdot \mathrm{g}^{-\mathrm{f}}\right]\end{array}$ & $\mathrm{TOF}^{b}\left[\mathrm{~s}^{-1}\right]$ \\
\hline \multirow[t]{2}{*}{$\mathrm{C} 100 / 0$} & $d r y$ & 250 & No activity & No activity & & 13.6 & - \\
\hline & wet & 210 & - & - & & 16.0 & - \\
\hline \multirow[t]{2}{*}{ C90/10 } & dry & 151 & 14 & 16 & 92 & 20.2 & 0.19 \\
\hline & wet & 163 & 15 & 17 & 77 & 18.1 & 0.17 \\
\hline \multirow[t]{2}{*}{$\mathrm{C} 80 / 20$} & $d r y$ & 123 & 26 & 34 & 245 & 22.2 & 0.46 \\
\hline & wet & 110 & 13 & 0 & 145 & 23.2 & 0.27 \\
\hline \multirow[t]{2}{*}{$\mathrm{C} 70 / 30$} & $d r y$ & 95 & 24 & 60 & 333 & 25.5 & 0.55 \\
\hline & wet & 86 & 22 & 78 & 293 & 22.2 & 0.54 \\
\hline \multirow[t]{2}{*}{ C60/40 } & $d r y$ & 96 & 36 & 39 & 350 & 18.1 & 0.80 \\
\hline & wet & 95 & 20 & 79 & 318 & 19.5 & 0.74 \\
\hline \multirow[t]{2}{*}{ C50/50 } & $d r y$ & 61 & 29 & 56 & 380 & 24.6 & 0.64 \\
\hline & wet & 64 & 20 & 72 & 349 & 22.2 & 0.64 \\
\hline \multirow[t]{2}{*}{$\mathrm{C} 40 / 60$} & $d r y$ & 48 & 22 & 50 & 385 & 23.9 & 0.67 \\
\hline & wet & 56 & 27 & 56 & 318 & 20.9 & 0.61 \\
\hline \multirow[t]{2}{*}{ D100/0 } & $d r y$ & 250 & $-{ }^{c}$ & $-{ }^{c}$ & & 12.9 & - \\
\hline & wet & 247 & 10 & 29 & 131 & 13.2 & 0.41 \\
\hline \multirow[t]{2}{*}{$\mathrm{D} 70 / 30$} & dry & 101 & 33 & 42 & 485 & 21.1 & 0.94 \\
\hline & wet & 104 & 38 & 37 & 426 & 20.7 & 0.84 \\
\hline \multirow[t]{2}{*}{ D60/40 } & $d r y$ & 113 & 32 & 43 & 482 & 15.5 & 1.27 \\
\hline & wet & 137 & 23 & 72 & 480 & 13.3 & 1.47 \\
\hline \multirow[t]{2}{*}{ D50/50 } & dry & 56 & 19 & 50 & 402 & 26.8 & 0.61 \\
\hline & wet & 59 & 20 & 67 & 460 & 25.0 & 0.75 \\
\hline \multirow[t]{2}{*}{ D40/60 } & $d r y$ & 42 & 29 & 53 & 433 & 26.7 & 0.66 \\
\hline & wet & 51 & 27 & 59 & 480 & 23.0 & 0.85 \\
\hline
\end{tabular}

a calculated from the $\mathrm{Cu}$ crystallite size based on XRD data obtained during reaction

${ }^{\mathrm{b}}$ hydrogen molecules produced per surface copper atom per second

${ }^{\mathrm{c}}$ fast deactivation

It can be seen from Table 2 that the D-series samples exhibit a higher hydrogen production rate than the samples of the $\mathrm{C}$-series. Furthermore, the samples prepared at constant $p H$ show a greater variation in $\mathrm{H}_{2}$ production rate than the D-series samples of similar $\mathrm{Cu}$ surface area.

The TOF for the initial activity as a function of $\mathrm{ZnO}$-content in the catalysts is given in Fig. 3. The reaction rate is normalized to the number of $\mathrm{Cu}$ metal surface atoms. It can be seen that the TOF values vary with the catalyst composition having maximum values of $0.80 \mathrm{~s}^{-1}$ for the 'dry' reduced Sample C60/40 and of $1.47 \mathrm{~s}^{-1}$ for the 'wet' reduced Sample D60/40. In addition, samples prepared at decreasing $p H$ show a higher TOF than the samples of the constant $p H$ series. The differences in the TOF for 'wet' reduced samples as compared to that of those which underwent 'dry' reduction is small.

\section{Oxygen addition cycle}

In Fig. 4 four XRD patterns of a $\mathrm{Cu} / \mathrm{ZnO}$ catalyst (sample C60/40) obtained after calcination (a), steam reforming (b), oxidation (c), and re-reduction (d) are displayed. The pattern indicative of $\mathrm{CuO}$ (a) is converted to that of metallic $\mathrm{Cu}$ (b) after the calcined sample is reduced in the steam reforming feed with no additional copper oxide phases detectable. The addition of $22 \mathrm{vol} \% \mathrm{O}_{2}$ to the feed at 523 $\mathrm{K}$ for $100 \mathrm{~min}$ resulted in the formation of mostly $\mathrm{Cu}(\mathrm{I})$ oxide together with some minor amounts of $\mathrm{Cu}$ (II) oxide (c). After re-reduction in the feed at $523 \mathrm{~K}$ the XRD pattern of metallic $\mathrm{Cu}$ can be seen, but with a decreased line width of the $\mathrm{Cu}$ (111) peak (d). Changes in the product gas phase composition $\left(\mathrm{H}_{2}, \mathrm{MeOH}, \mathrm{CO}_{2}\right.$, and $\left.\mathrm{H}_{2} \mathrm{O}\right)$ during two oxygen addition cycles are depicted in Fig. 5 . It can be seen that adding oxygen to the feed resulted in a complete bss of activity for the steam reforming reaction. In addition, the formation of water and $\mathrm{CO}_{2}$ during the oxygen addition indicates the occurrence of total oxidation of methanol. The low hydrogen concentration observed during oxygen addition intervals might result from methanol dehydrogenation. The oxidative poisoning was, however, completely reversible with no loss in hydrogen productivity. Oxidation and re-reduction experiments were carried out on selected samples (C70/30, C60/40, C40/60) activated under 'dry' reduction conditions. The copper crystallite sizes, the methanol conversion, and selectivity are summarized in Table 3. An increase in conversion, selectivity, and hydrogen production rate with extending number of oxidation-reduction cycles is observed. In addition, the copper crystallite size expands with each oxidation cycle (Table 3 ). 
Table 3 Change of catalytic activity data (conversion of methanol, selectivity to $\mathrm{CO}_{2}$, hydrogen production rate) obtained in $\mathrm{XRD}$ and XAS cells after repeated oxidation and reduction steps. All samples were prepared according to the constant $p H$ method and reduced at 'dry' conditions. The data was obtained at $523 \mathrm{~K}$ with a flow of $\mathrm{MeOH} / \mathrm{H}_{2} \mathrm{O}(\mathrm{ratio} \sim 4 / 1)$ in $120 \mathrm{ml} / \mathrm{min}$ (XRD cell) or $25 \mathrm{ml} / \mathrm{min}$ (XAS cell) Conversion and selectivity are given as initial values.

\begin{tabular}{|c|c|c|c|c|c|c|c|c|}
\hline \multirow{2}{*}{ Sample name ${ }^{a}$} & \multirow{2}{*}{$\begin{array}{c}\text { Number of } \\
\text { oxidation/red } \\
\text { uction } \\
\text { cycles }\end{array}$} & \multirow{2}{*}{$\begin{array}{c}\mathrm{Cu} \\
\text { crystallite } \\
\text { size }[\AA]^{\mathrm{a}}\end{array}$} & \multicolumn{3}{|c|}{ XRD cell } & \multicolumn{3}{|c|}{ XAS cell } \\
\hline & & & $\begin{array}{c}\mathrm{X}_{\mathrm{MeOH}} \\
{[\%]}\end{array}$ & $\begin{array}{l}\mathrm{S}_{\mathrm{CO} 2} \\
{[\%]}\end{array}$ & 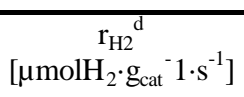 & $\begin{array}{c}\mathrm{X}_{\mathrm{MeOH}} \\
{[\%]}\end{array}$ & $\begin{array}{l}\mathrm{S}_{\mathrm{CO} 2} \\
{[\%]}\end{array}$ & $\begin{array}{c}\mathrm{r}_{\mathrm{H} 2}{ }^{\mathrm{d}} \\
{\left[\mu \mathrm{molH}_{2} \cdot \mathrm{g}_{\mathrm{cat}}{ }^{-1} \cdot \mathrm{s}^{-1}\right]}\end{array}$ \\
\hline \multirow[t]{3}{*}{$\mathrm{C} 70 / 30$} & 0 & 76 & 25 & 75 & 483 & 25 & 54 & 145 \\
\hline & 1 & 110 & 62 & 61 & 531 & 25 & 58 & 155 \\
\hline & $2^{\mathrm{c}}$ & 120 & - & - & - & 23 & 70 & 166 \\
\hline \multirow[t]{3}{*}{ C60/40 } & 0 & 100 & 51 & 37 & 470 & 20 & 48 & 133 \\
\hline & 1 & 120 & 64 & 42 & 556 & 26 & 51 & 162 \\
\hline & 2 & 130 & 62 & 42 & 535 & 27 & 53 & 176 \\
\hline \multirow[t]{3}{*}{$\mathrm{C} 40 / 60$} & 0 & 50 & 40 & 50 & 450 & 20 & 53 & 150 \\
\hline & 1 & 70 & 44 & 80 & 620 & 24 & 53 & 160 \\
\hline & 2 & 80 & 36 & 94 & 618 & - & - & - \\
\hline \multirow[t]{2}{*}{ C30/70 } & 0 & $-{ }^{c}$ & - & - & & 20 & 53 & 105 \\
\hline & 1 & & & & & 24 & 53 & 146 \\
\hline \multirow[t]{3}{*}{$\mathrm{C} 10 / 90$} & 0 & - & - & - & & 13 & 55 & 92 \\
\hline & 1 & & & & & 14 & 55 & 92 \\
\hline & 2 & & & & & 14 & 62 & 103 \\
\hline
\end{tabular}

${ }^{a}$ based on the Scherrer equation for the $\mathrm{Cu}$ (111) reflection

b " 0 " denotes the fresh reduced catalyst, where " 1 " and " 2 " refer to first and second oxidation/reduction cycle, respectively ${ }^{\mathrm{c}}$ second oxidation step not performed

${ }^{\mathrm{d}}$ production rate of hydrogen per $\mathrm{g}$ catalyst and second

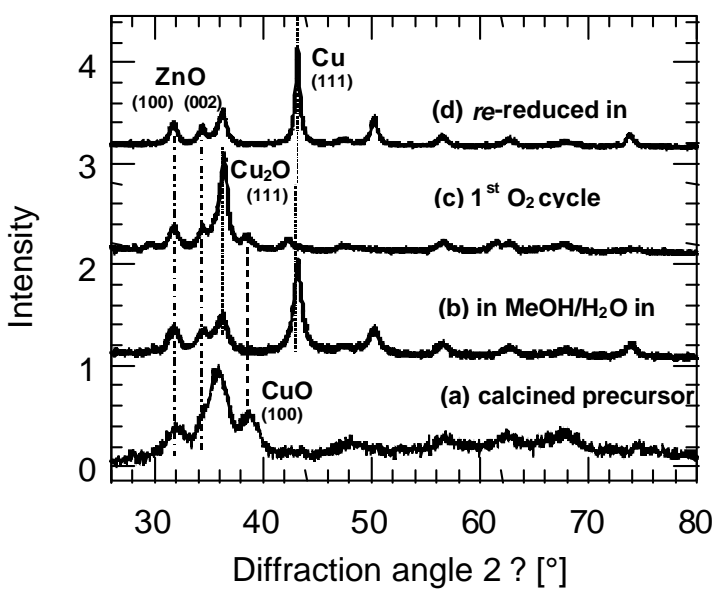

Fig. 4 X-ray diffraction patterns of a sample with a composition of 60 at- $\% \mathrm{Cu}$ and 40 at-\% $\mathrm{Zn}$ (C60/40) during different stages of treatment. Upon reduction the calcined $\mathrm{CuO}$ (a) is transformed into $\mathrm{Cu}$ metal which is preserved under methanol steam reforming conditions at $523 \mathrm{~K}$ (b). Oxygen treatment resulted in a mixture of $\mathrm{Cu}(\mathrm{I})$ oxide and $\mathrm{Cu}$ (II) oxide (c). The oxidic copper phases are re-reduced in the feed to metallic $\mathrm{Cu}$ with a decreased line width (d). Characteristic $(h k l)$ diffraction lines of $\mathrm{CuO}, \mathrm{Cu}_{2} \mathrm{O}$, and $\mathrm{Cu}$ metal are indicated.

For example, the copper crystallite size of the sample C70/30 increases from 76 to $110 \AA$ and then to $120 \AA$. After the oxidation-reduction cycles the XRD peaks of $\mathrm{ZnO}$ (e.g. (100), (002)) are similarly affected in that their profiles become gradually more pronounced. Profile fitting of the $\mathrm{ZnO}$ (100) peak of $\mathrm{C} 70 / 30$ sample gives crystallite sizes that increase slightly upon oxidation and re-reduction from 80 to $90 \AA$. The relative changes of the copper and zinc oxide lattice parameter after reduction, under stream reforming conditions, and after successive oxygen/rereduction cycles are depicted in Fig. 6.

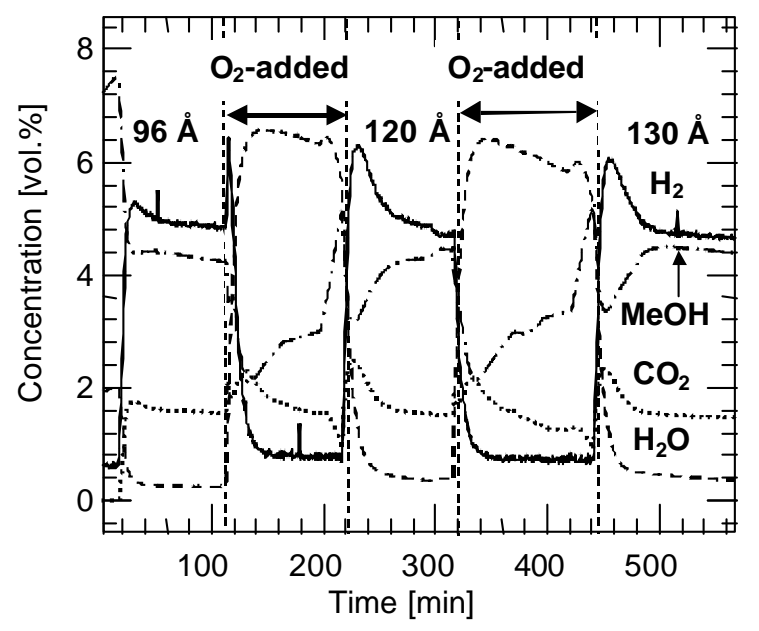

Fig. 5 Evolution of gas phase concentration of $\mathrm{H}_{2}$, $\mathrm{MeOH}, \mathrm{CO}_{2}$, and $\mathrm{H}_{2} \mathrm{O}$ in XRD cell under methanol steam reforming conditions during addition of oxygen (15 vol-\% $\mathrm{O}_{2}$ ) to the feed for two intervals of $\sim 100 \mathrm{~min}$. Sample C60/40 'dry' was used. The change of $\mathrm{Cu}$ crystallite size is also indicated. 


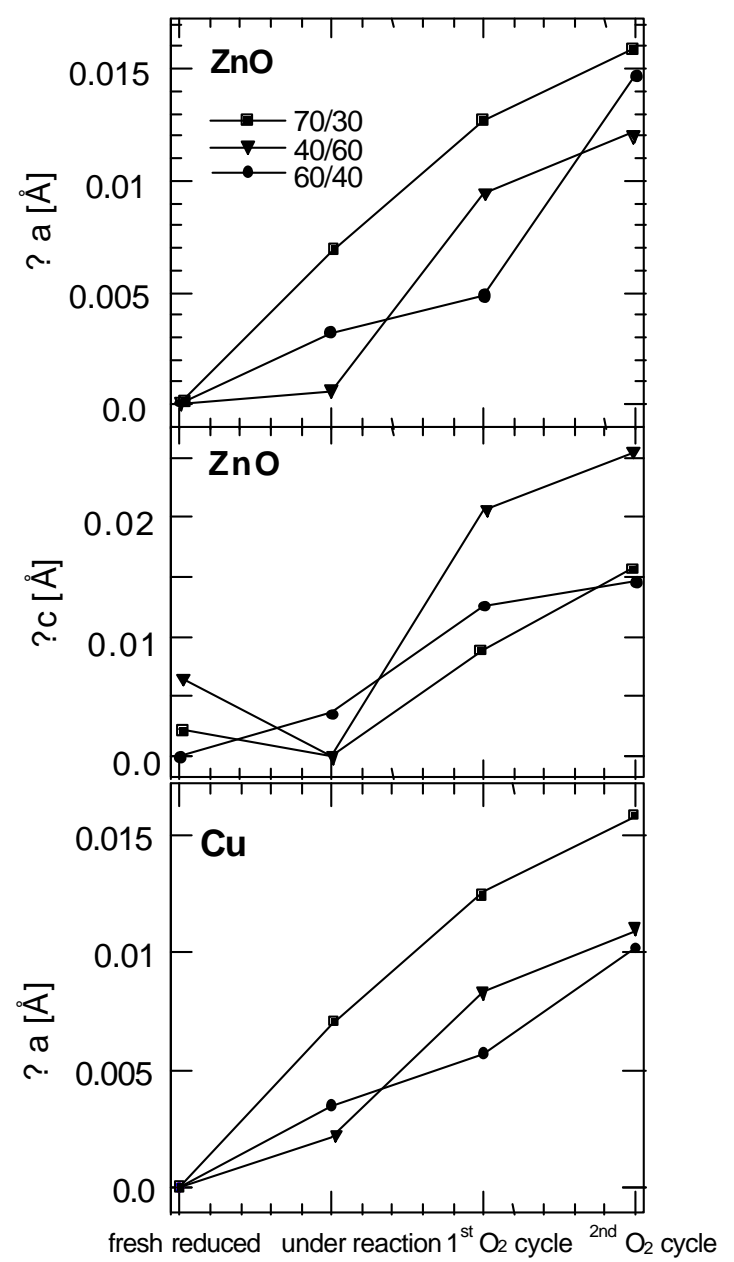

Fig. 6 Relative change of $\mathrm{ZnO}$ lattice parameters $a$ and $c$ (a) and $\mathrm{Cu}$ lattice parameter $a$ (b) with respect to the values of the fresh reduced samples C70/30, C60/40, and C40/60 under methanol steam reforming, and after two successive oxygen addition cycles.

The continuous increase in lattice parameter of $\mathrm{Cu}$ and $\mathrm{ZnO}$ indicates an expansion of the unit cell under methanol steam reforming conditions after each oxidation/rereduction steps with respect to the freshly reduced sample.

\section{II.) In situ XAFS}

a) Reduction of $\mathrm{CuO} / \mathrm{ZnO}$ precursor

In situ X-ray absorption spectroscopy was performed at the $\mathrm{Cu} \mathrm{K}$ edge to determine the evolution of the short-range structure of the less crystalline or amorphous copper phases which are not accessible by the in situ XRD measurements under reaction conditions. A principal component analysis of the $\mathrm{Cu} \mathrm{K}$ edge XANES spectra revealed that three primary components were necessary to reconstruct the experimental XANES spectra. Using target transformation three probable reference compounds (i. e. $\mathrm{Cu}, \mathrm{Cu}$ (I) oxide, $\mathrm{Cu}$ (II) oxide) were identified. In situ XRD results have shown that $\mathrm{Cu}$ in the oxide precursor was $\mathrm{CuO}$ and that it was completely reduced by TPR to $\mathrm{Cu}$. The "target-transformed" spectra showed a good match with the first experimental XANES spectrum (containing only $\mathrm{CuO}$ ) and the last spectrum (containing only $\mathrm{Cu}$ ) in the TPR run. However, the result of the transformation for the third component showed considerable deviations from the experimental spectra of commercially available pure $\mathrm{Cu}_{2} \mathrm{O}$. The poor match is probably due to the high crystallinity of the reference compound which may not reflect the local disorder (structural defects, decreased crystallinity and/or crystallite size) of the intermediately formed $\mathrm{Cu}(\mathrm{I})$ oxide. In order to account for the small crystallite sizes a reduction of the amplitude above the XANES edge of the experimental spectra resulted in an enhanced agreement with the transformed spectra. Hence, $\mathrm{Cu}(\mathrm{I})$ oxide is indeed an intermediate during TPR and the "target-transformed" spectrum was taken as a reference for $\mathrm{Cu}(\mathrm{I})$ oxide for the least square fits. The evolution of the phase composition during TPR of Sample D70/30 under 'dry' reduction conditions ( 2 vol- $\% \mathrm{H}_{2}$ in $25 \mathrm{ml} / \mathrm{min} \mathrm{He}$, temperature ramp $448 \mathrm{~K}$ to $523 \mathrm{~K}$ at $5 \mathrm{~K} / \mathrm{min}$ ) is depicted in Fig. 7. It can be seen that the onset of reduction coincides with the evolution of $\mathrm{H}_{2} \mathrm{O}$ and the uptake of $\mathrm{H}_{2}$.

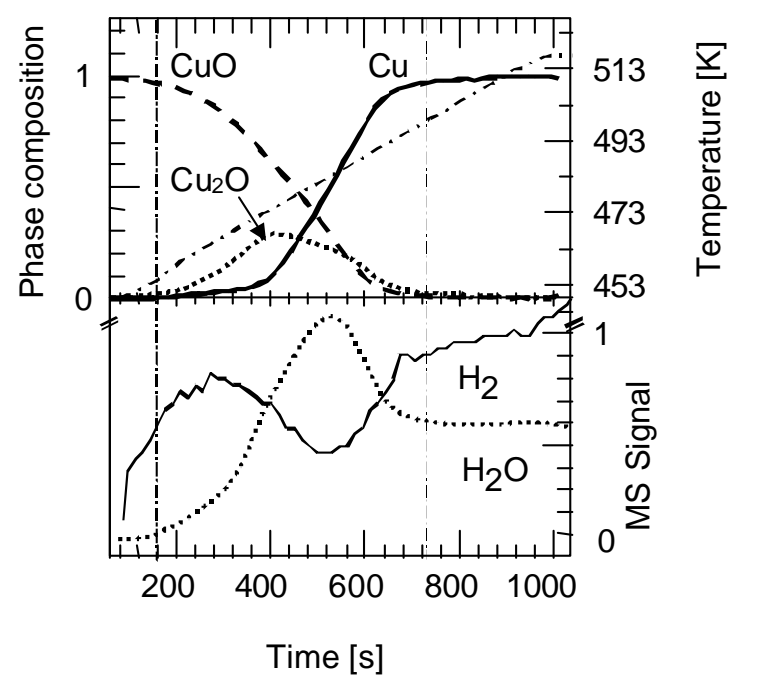

Fig. 7 Evolution of copper phase composition together with the MS signal of $\mathrm{H}_{2} \mathrm{O}$ (dotted) and $\mathrm{H}_{2}$ (solid) during TPR. The quantitative phase analysis is based on a least squares fit of $\mathrm{Cu} \mathrm{K}$ edge XANES spectra of a $\mathrm{CuO} / \mathrm{ZnO}$ sample (C70/30) during TPR in 8 vol\% $\mathrm{H}_{2}$ with $5 \mathrm{~s} /$ frame and a heating rate of $5 \mathrm{~K} / \mathrm{min}$ using suitable reference spectra of $\mathrm{Cu}, \mathrm{Cu}(\mathrm{I})$ oxide, and $\mathrm{CuO}$ as described in the text.

\section{b) Steam reforming of methanol}

In Fig. 8 the $\mathrm{Cu} \mathrm{K}$ edge XANES spectra measured over a period of 20 min during oxygen addition to the feed at $523 \mathrm{~K}$ is presented. It can be seen that adding $\mathrm{O}_{2}$ to the feed (15 vol\%) results in an increase of the $\mathrm{Cu} \mathrm{K}$ pre-edge feature. This corresponds to the oxidation of $\mathrm{Cu}$ to form $\mathrm{Cu}(\mathrm{I})$ oxide and $\mathrm{Cu}(\mathrm{II})$ oxide. The evolution of the concentration of $\mathrm{MeOH}, \mathrm{H}_{2}, \mathrm{H}_{2} \mathrm{O}$ and $\mathrm{CO}_{2}$ together with traces of methylformate and $\mathrm{CO}$ (lower part of the graph) during two oxygen addition cycles are depicted in Fig. 9. It can be seen that after each oxygen and subsequent 
reduction cycle the resulting catalyst produces an increased hydrogen concentration as compared to that obtained after the initial reduction in $5 \% \mathrm{H}_{2}$. The catalytic performance after two oxidation/reduction cycles of a number of samples is given in Table 3 .

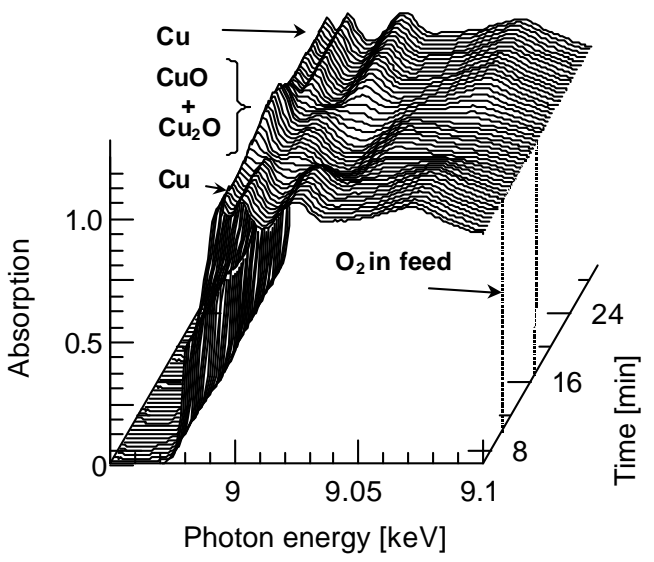

Fig. 8 Evolution of $\mathrm{Cu}$ K-edge XANES of $\mathrm{CuO} / \mathrm{ZnO}$ at $523 \mathrm{~K}$ during oxygen addition to a methanol steam reforming feed $\left(\mathrm{c}(\mathrm{MeOH}) \sim 6\right.$ vol- $\%, \mathrm{c}\left(\mathrm{H}_{2} \mathrm{O}\right) \sim 1.5$ vol- $\%$ in $25 \mathrm{ml} / \mathrm{min} \mathrm{He}$ ). Different $\mathrm{Cu}$ phases are indicated.

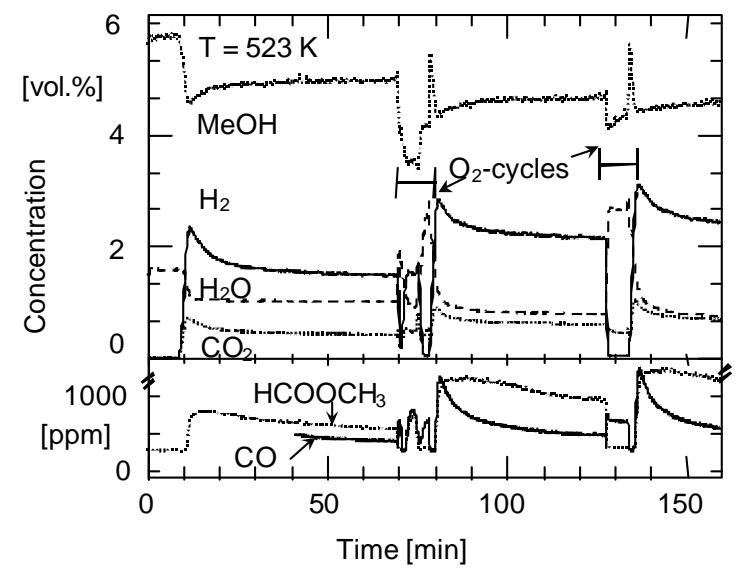

Fig. 9 Evolution of gas phase composition $\left(\mathrm{H}_{2}, \mathrm{MeOH}\right.$. $\mathrm{CO}_{2}$, and $\mathrm{H}_{2} \mathrm{O}$ ) during oxygen addition to a methanol steam reforming feed in the in situ XAFS cell. Concentration of $\mathrm{CO}$ and $\mathrm{HCOOCH}_{3}$ is shown in the bottom part of the graph (sample C60/40).

The evolution of the copper bulk phases (i. e. formation of $\mathrm{CuO}_{1-\mathrm{x}}$ and re-reduction) and the corresponding gas phase composition during one oxygen addition to the feed is shown in Fig. 10. It can be seen that oxygen in the feed leads to a rapid oxidation of the copper particles to $\mathrm{Cu}(\mathrm{I})$ oxide and $\mathrm{Cu}$ (II) oxide (with a ratio of $\sim 3 / 1$ ). After the $\mathrm{O}_{2}$ has been switched off the catalyst is re-reduced in the feed, the $\mathrm{CO}$ and $\mathrm{H}_{2} \mathrm{O}$ concentrations decrease, and the $\mathrm{H}_{2}$ concentration increases. Apparently, reversible changes of the oxidation state of copper can be observed during oxygen cycles due to oxidation and subsequent re-reduction processes in the feed (see Fig. 8). A catalytic activity similar to that before the oxidation is regained after $4 \mathrm{~min}$. at which time only copper metal can be detected.

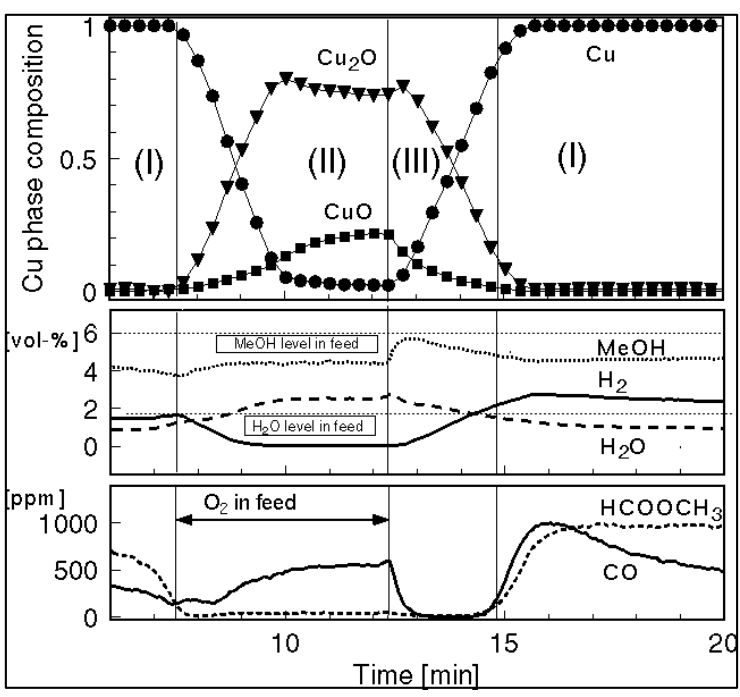

Fig. 10 Evolution of $\mathrm{Cu}$ phase composition during oxygen addition cycles into steam reforming feed at $523 \mathrm{~K}$. Phase analysis was obtained form least-squares fit of reference spectra to the corresponding XANES spectra shown in Fig. 9. The two lower sections of the graph depict the evolution of the gas phase in percent and ppm, respectively. Three transitions in bulk and gas phase composition are marked: I.) copper metal during steam reforming, II.) oxidation to $\mathrm{CuO}_{1-\mathrm{x}}$, III.) re-reduction of $\mathrm{CuO}_{1-\mathrm{x}}$ phases.

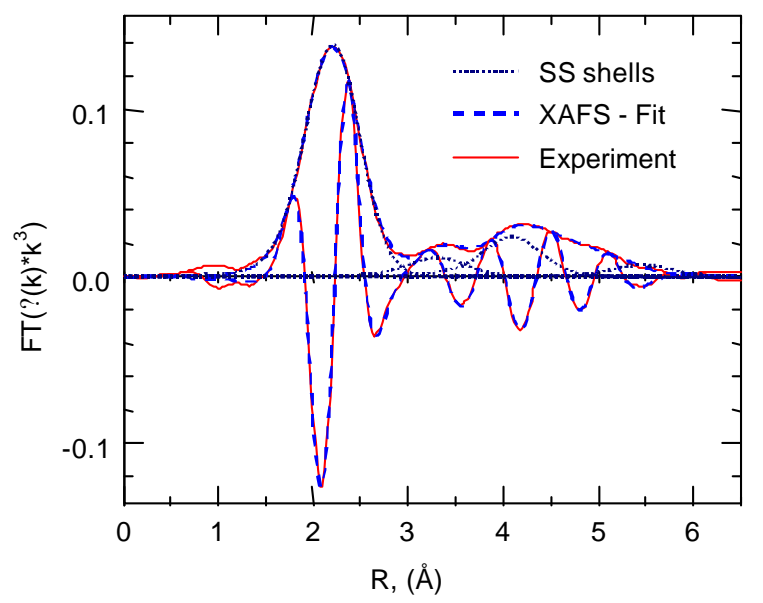

Fig. 11 Refinement of a sum of theoretical EXAFS function (dashed line) of $\mathrm{Cu}$ to an experimental FT(? (k)) of sample $\mathrm{C} 70 / 30$ at $523 \mathrm{~K}$ after reduction in 2 vol\% $\mathrm{H}_{2}$. Only the four strongest single scattering EXAFS functions are indicated (thin dark lines). Fitted parameters are found in Table 4.

The extended fine structure (EXAFS) of the experimental XAFS spectra measured under reaction conditions at the $\mathrm{Cu}$ $\mathrm{K}$ and $\mathrm{Zn} \mathrm{K}$ edges was investigated to analyze changes in the short-range order structure of $\mathrm{Cu}$ and $\mathrm{ZnO}$ during repeated oxidation and re-reduction cycles at $523 \mathrm{~K}$ during methanol steam reforming. In Fig. 11 a refinement of a theoretical $\mathrm{Cu}$ EXAFS function to an experimental $\mathrm{Cu}$ FT(? (k)) of sample C70/30 at $523 \mathrm{~K}$ under steam reforming conditions is depicted. Only the four most intense single 
scattering paths in copper metal are displayed and a good agreement between experimental data and fit can be seen.

Table 4 Structural parameters of $\mathrm{Cu} / \mathrm{ZnO}(\mathrm{C} 70 / 30)$ at 523 $\mathrm{K}$ under methanol steam reforming conditions (Fig. 11) obtained from a refinement of theoretical EXAFS functions calculated for $\mathrm{Cu}$ metal cluster $\left(\mathrm{k}=2.0\right.$ to $13.0 \AA^{-1}, \mathrm{R}=1.5$ to $6.0 \AA, \mathrm{N}_{\text {ind }}=32, \mathrm{~N}_{\text {free }}=12,5$ single scattering paths and 14 multiple scattering paths). Parameters refined are $\mathrm{E}_{0}$ $(\mathrm{Cu})=3.83 \mathrm{eV}$. The fit residual amounted to 2.8. Based on shells \# 1, 2, 3, 5 an average lattice constant of $\mathrm{a}_{0}=3.6410$ $\AA(\mathrm{Cu}, F m 3 m)$ was obtained.

\begin{tabular}{|l|c|c|c|c|c|}
\hline Shell & $\begin{array}{c}\mathrm{CN} \\
\text { fixed }\end{array}$ & $\mathrm{R},(\AA)$ & $\begin{array}{c}?_{\mathrm{R}} \\
(\AA) \\
(\AA)\end{array}$ & $\begin{array}{c}?^{2}, \\
\left(\AA^{2}\right)\end{array}$ & W (\%) \\
\hline & & & & & \\
\hline $1 . \mathrm{Cu}-\mathrm{Cu}$ & 12 & 2.552 & -0.004 & 0.0158 & 100 \\
\hline $2 . \mathrm{Cu}-\mathrm{Cu}$ & 6 & 3.647 & 0.032 & 0.0246 & 9.567 \\
\hline $3 . \mathrm{Cu}-\mathrm{Cu}$ & 24 & 4.437 & 0.01 & 0.0258 & 19.86 \\
\hline $4 . \mathrm{Cu}-\mathrm{Cu}$ & 12 & 5.098 & 0.014 & 0.0963 & 0.443 \\
\hline 5. Cu - Cu & 24 & 5.826 & 0.111 & 0.030 & 6.187 \\
\hline
\end{tabular}

The refined structural parameters are given in Table 4 . During the fit the coordination numbers of $\mathrm{Cu}$ were kept constant to the values of bulk copper. This restriction is a reasonable assumption for the particle sizes investigated which have been shown by XRD to be larger than $80 \AA$. Therefore, size effects are assumed to play only a minor role in reduction of the amplitude in the FT(?(k)) (40). Here the Debye-Waller (DW) factor is treated as a fitting parameter with coordination numbers fixed to those of the bulk metal. Hence, the Debye-Waller factor will be used to account for the apparent structural disorder in the copper crystallites and for the associated reduction in amplitude in the FT $(?(\mathrm{k}))$.

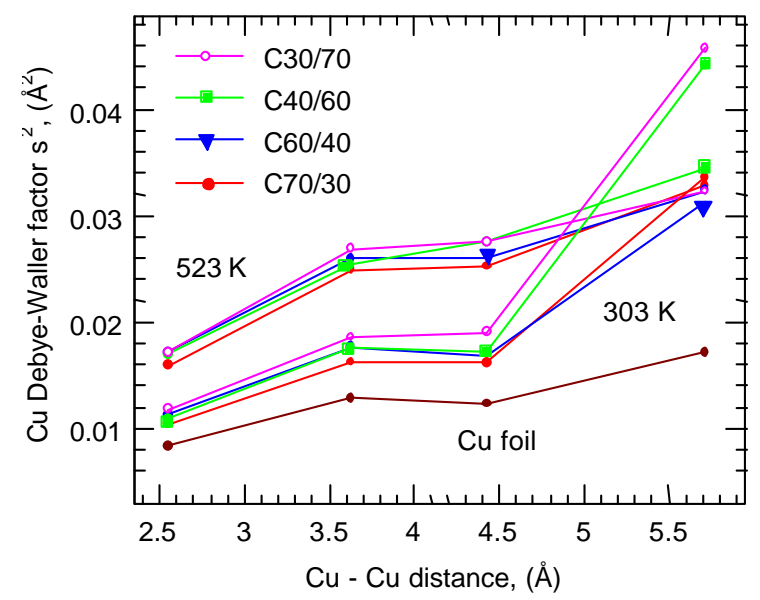

Fig. 12 Cu Debye-Waller (DW) Factors, ? ${ }^{2}$, for the first, second, third, and fifth $\mathrm{Cu}-\mathrm{Cu}$ distance obtained from a refinement of a theoretical EXAFS function to experimental data for reduced samples C70/30, C60/40, $\mathrm{C} 40 / 60, \mathrm{C} 30 / 70$ and $\mathrm{Cu}$ foil obtained at $303 \mathrm{~K}$ and $523 \mathrm{~K}$ under methanol steam reforming conditions.
In the EXAFS analysis the Debye-Waller factors for the first, second, third, and fifth $\mathrm{Cu}-\mathrm{Cu}$ shells are determined from a refinement of a theoretical EXAFS function to the experimental EXAFS functions of reduced binary samples measured at room temperature and at $523 \mathrm{~K}$ (shown in

Fig. 12). For comparison, the DW factors obtained for a copper foil at room temperature are also given. It can be seen that the DW factors for the first three $\mathrm{Cu}-\mathrm{Cu}$ shells for the samples at $523 \mathrm{~K}$ are higher than for those measured at room temperature. However, for samples C70/30 and C60/40 the DW factors of the fifth shell $(5.7 \AA)$ are about the same as those of the samples measured at room temperature. For samples $\mathrm{C} 40 / 60$ and $\mathrm{C} 30 / 70$ the DW factors are even lower at $523 \mathrm{~K}$ than at room temperature.

(a)

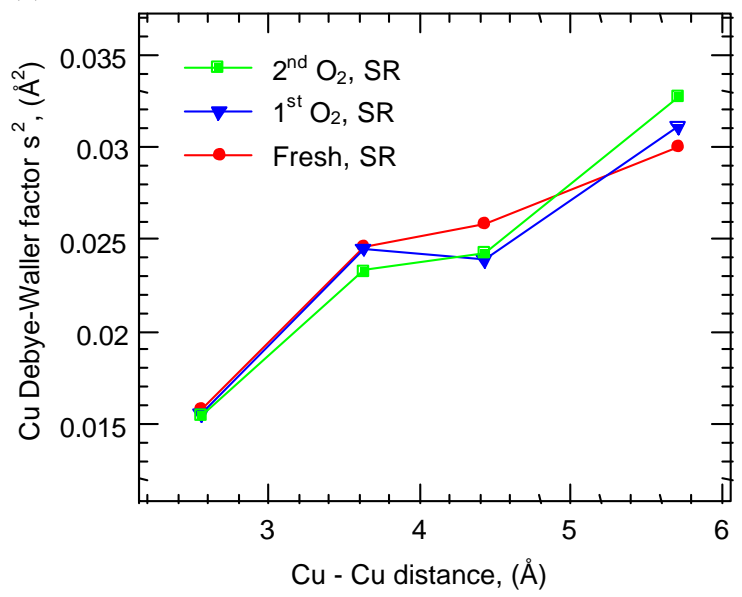

(b)

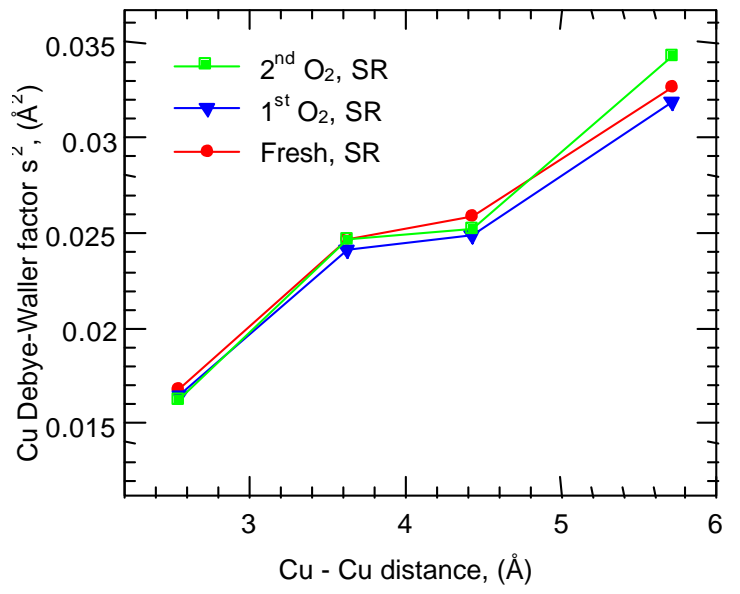

Fig. 13 Cu Debye-Waller (DW) Factors, ? ${ }^{2}$, for the first, second, third, and fifth $\mathrm{Cu}-\mathrm{Cu}$ distance obtained from a refinement of a theoretical EXAFS function to experimental data for sample C70/30 (a) and C60/40 (b) obtained at $523 \mathrm{~K}$ during methanol steam reforming conditions after different pretreatment (fresh reduced) and after two subsequent oxidation and reduction steps (denoted as $1^{s t} \mathrm{O}_{2}, \mathrm{SR}$ and $2^{\text {nd }} \mathrm{O}_{2}, \mathrm{SR}$ step).

The DW factors of the $\mathrm{Cu}$ foil are the lowest in all cases. After an oxidation addition cycle at $523 \mathrm{~K}$ the amplitude of the FT increases, indicating structural changes with respect to the fresh reduced catalyst. A smaller increase in FT(? $(\mathrm{k}))$ 
is noted after the second oxidation cycle. The variation of the $\mathrm{Cu} \mathrm{DW}$ factors for the first, second, third, and fifth $\mathrm{Cu}-$ $\mathrm{Cu}$ distance obtained from fitting experimental spectra of samples $\mathrm{C} 70 / 30$ and $\mathrm{C} 60 / 40$ obtained under working conditions at $523 \mathrm{~K}$ for different oxidative treatments is displayed in Fig.13 a and b. An increasing Debye-Waller factor for the fifth $\mathrm{Cu}$ shell is detected for both samples after the second oxygen addition cycle. This effect seems to indicate an increasing medium range structural disorder in the copper particles with repeated oxygen addition cycles. Furthermore, changes in the local structural order of $\mathrm{ZnO}$ after oxidation/re-reduction cycles under reaction conditions were observed. In Fig. 14 the evolution of the experimental $\mathrm{FT}(?(\mathrm{k}))$ of $\mathrm{ZnO}$ in sample $\mathrm{C} 70 / 30$ at $523 \mathrm{~K}$ during methanol steam reforming after initial reduction and after two oxidation/re-reduction cycles is depicted. A significant increase in amplitude of the FT(? (k)) is clearly detectable with repeated $\mathrm{O}_{2}$-addition cycles. Especially for the $\mathrm{Zn}-\mathrm{Zn}$ distance at $2.8 \AA$ a continuous increase can be seen. Higher shells also become more developed after repeated oxidation cycles. The observation of the increasing amplitude for both $\mathrm{Cu}$ and $\mathrm{ZnO}$ after oxidation and re-reduction implies that $\mathrm{ZnO}$ undergoes microstructural modification during oxidation/re-reduction cycles as well. To further elucidate the structural changes in the short-range order of $\mathrm{ZnO}$ after oxidation/re-reduction cycles, a refinement of theoretical EXAFS functions to the experimental spectra was performed.

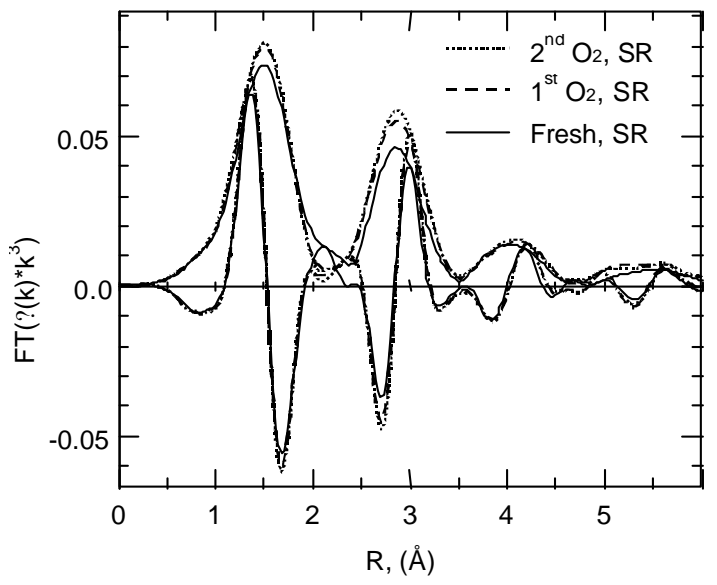

Fig. 14 Experimental Fourier transformed $\mathrm{Zn} \mathrm{K}$ edge ?(k) (magnitude and imaginary part) of $\mathrm{ZnO}$ for sample $\mathrm{C} 70 / 30$ obtained at $523 \mathrm{~K}$ during methanol steam reforming reaction after different pretreatment (fresh reduced) and after two subsequent oxidation and reduction steps (denoted as $1^{s t} \mathrm{O}_{2}$, SR and $2^{\text {nd }} \mathrm{O}_{2}, \mathrm{SR}$ step).

As an example,

Fig. 15 (a) shows the fit of a theoretical EXAFS function of $\mathrm{ZnO}$ to the experimental Zn K FT(? (k)) of sample C70/30 under steam reforming conditions at $523 \mathrm{~K}$. A significant deviation in amplitude and imaginary part of the FT(? (k)) is observed between the experimental and the fitted spectra. However, by adding $\mathrm{Zn}-\mathrm{Cu}$ shells for $\mathrm{Zn}$ atoms occupying
$\mathrm{Cu}$ sites in $\mathrm{Cu}$ clusters a much better fit to the experimental FT is obtained as shown in

Fig. 15 (b).

(a)

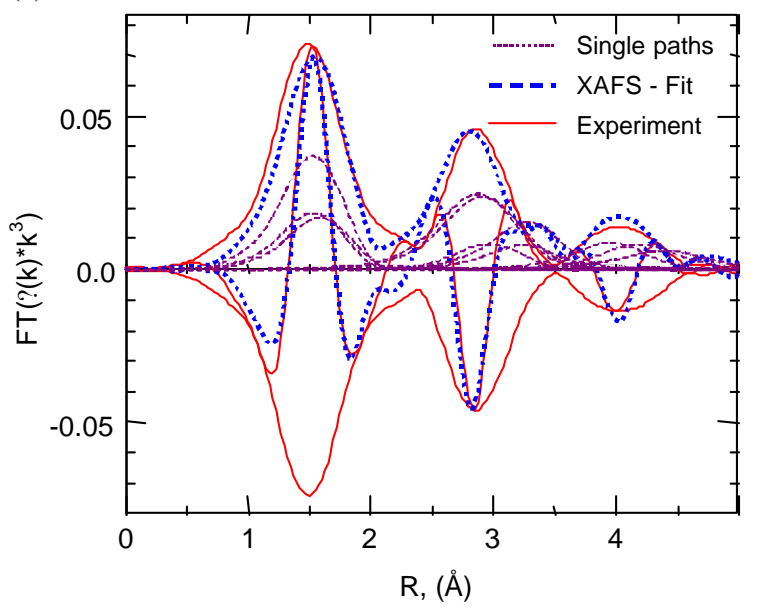

(b)

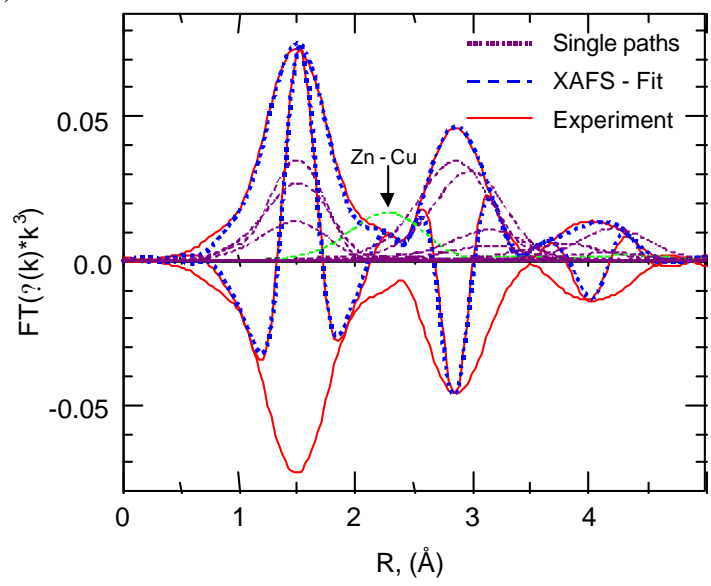

Fig. 15 Refinement of a theoretical EXAFS function (dotted line) of $\mathrm{ZnO}$ to an experimental $\mathrm{FT}(?(\mathrm{k}))$ for the sample C70/30 after reduction in 2 vol\% $\mathrm{H}_{2}$ at $523 \mathrm{~K}$ (a) pure $\mathrm{ZnO}$ and (b) assuming additional $\mathrm{Zn}-\mathrm{Cu}$ shells by doping $\mathrm{Zn}$ into the $\mathrm{Cu}$ cluster.

This indicates that $\mathrm{Zn}$ in $\mathrm{Cu}$ clusters contributes significantly to the $\mathrm{FT}(?(\mathrm{k}))$ of $\mathrm{ZnO}$. By quantitative EXAFS-fitting of a sum of the two phases $(\mathrm{ZnO}+\mathrm{Zn}$ in $\mathrm{Cu}$ ) it is possible to determine the amount of $\mathrm{Zn}$ in the $\mathrm{Cu}$ clusters. For sample C70/30 the contribution to the total amplitude from scattering paths of $\mathrm{Zn}$ in $\mathrm{Cu}$ for the fresh reduced sample under reaction conditions amounts to $10 \%$. This amount diminishes to $5.1 \%$ after the first oxygen addition cycle and to $2.6 \%$ after the second cycle. By relating the contributions of scattering paths of $\mathrm{Zn}$ in $\mathrm{Cu}$ to the nominal $\mathrm{Zn}$-content of the samples, the concentration of $\mathrm{Zn}$ in $\mathrm{Cu}$ can be estimated. For the fresh reduced sample $\mathrm{C} 70 / 304.3 \mathrm{~mol} \% \mathrm{Zn}$ was found to be dissolved in copper. After the first and second oxygen addition cycles the concentration of $\mathrm{Zn}$ in $\mathrm{Cu}$ was 2.2 and 1.1 mol\%, respectively. For the sample C60/40 an amount of $2.4 \mathrm{~mol}$ $\%$ is dissolved in the $\mathrm{Cu}$ bulk of the fresh reduced sample, 
and this was reduced to $1.3 \mathrm{~mol} \%$ and then $0.8 \mathrm{~mol}-\%$ after oxygen addition cycles.

\section{Discussion}

\section{I.) In situ XRD}

Dependence of reducibility on catalyst composition

The presence of water retards the reduction onset temperature $(\sim 10 \mathrm{~K})$ and results in higher $\mathrm{Cu}$ crystallite sizes (Fig. 2). Although the $\mathrm{Cu} / \mathrm{Zn}$ ratio has only a slight effect on the onset temperature samples with increasing $\mathrm{Zn}$ content have smaller $\mathrm{Cu}$ particle sizes. The decreasing slope of the temperature-dependent $\mathrm{Cu}$ crystallite size with increasing $\mathrm{Zn}$ content seen in Fig. 2 indicates that $\mathrm{ZnO}$ exerts a stabilizing influence on the $\mathrm{Cu}$ particles during temperature programmed reduction. Fig. 2 (a) + (b) illustrate that during TPR the samples with the highest $\mathrm{Zn}$ concentration (samples with C40/60 and D40/60) exhibit only minor crystallite growth with increasing temperature, whereas the $\mathrm{Cu}$ clusters in samples with a higher $\mathrm{Cu}$ concentration tend to sinter more. Apparently, the tendency to sinter depends on the interaction with the $\mathrm{ZnO}$-matrix and the $\mathrm{Cu} / \mathrm{Zn}$ ratio. These results confirm previous investigations concerning the function of $\mathrm{ZnO}$ to keep the $\mathrm{Cu}$ crystallites in a dispersed state and thus maintaining a high surface area as previously described by Chinchen et al. (41) and Spencer (42). The exception to the previously mentioned trends are the samples with 60 mol\% $\mathrm{Cu}$ (C60/40 and D60/40) which show after reduction a $\mathrm{Cu}$ crystallite size that is $10 \AA$ larger than that of the sample with 70 mol\% $\mathrm{Cu}(\mathrm{C} 70 / 30$ and D70/30). The dependence of the reduction rate of $\mathrm{CuO}$ on the precursor composition is in good agreement with previous results by Porta et al. (19) and Himelfarb et al. (17) from an in situ XRD study. We have shown that for $\mathrm{Zn}$ concentrations larger than 40 mol-\% the multiphasic composition of the hydroxycarbonate precursor shows a transition from the rosasite phase $\left((\mathrm{Cu}, \mathrm{Zn})_{2}(\mathrm{OH})_{2} \mathrm{CO}_{3}\right)$ to the aurichalcite phase $\left((\mathrm{Cu}, \mathrm{Zn})_{5}(\mathrm{OH})_{6}\left(\mathrm{CO}_{3}\right)_{2}\right)$ (27). The influence of the precursor structure which is apparently preserved in the calcined $\mathrm{CuO} / \mathrm{ZnO}$ precursor can lead to an enhanced reduction rate through the beneficial interaction of various types of defects leading to an increased reactivity of the solid phase. Those defects may be introduced during calcination of the hydroxycarbonate precursor at mild decomposition temperatures affording a high density of defects in the oxide. Our results support previous findings by Shen et al. (26) and Porta et al. (19) on the effect of hydroxycarbonate precursor phases on the reducibility and $\mathrm{Cu}$ crystallite size. Furthermore, the nucleation process influences the reduction rate and it can be imagined that the interaction of the $\mathrm{Cu}$ metal nucleus with $\mathrm{ZnO}$ can lead to differences in the growth in three dimensions (19). In most cases the addition of water in 'wet' reduction experiments caused a shift of the onset of reduction to higher temperatures (Table 1). The influence of water addition could be explained by both thermodynamic and kinetic effects. First, the water partial pressures employed for the 'wet' TPR ( 30 mbar) experiments dilutes the hydrogen and results in an increased formation temperature of the $\mathrm{Cu}$ phase due to the reduced reduction potential (43). Second, the inhibition of the reduction by additional water according to the law of mass action can occur as well. Third, there may be a retarding influence of water on the formation of $\mathrm{Cu}$ nuclei. This kinetic explanation has been previously discussed by Wimmers et al. for a TPR study of $\mathrm{Fe}_{2} \mathrm{O}_{3}$ particles under 'wet' reduction conditions (44).

\section{Effects of precursor preparation and reduction conditions on the catalytic performance}

The influences of the $\mathrm{Cu} / \mathrm{Zn}$ ratio and the reduction method on the selectivity in methanol steam reforming are discussed for both constant and decreasing $p H$ sample preparation methods. Most samples exhibit an increasing selectivity with decreasing conversion. For instance, the selectivities of samples C50/50 and D50/50 increase from $\sim 70 \%$ to $\sim 80 \%$ while the conversion drops from 20 to $10 \%$. The reduction procedure affects the catalytic selectivity more clearly than the $p H$ during precipitation of the precursors. This dependence of the selectivity on the reduction conditions is in contrast to the TOF which seems to be unaffected by the reduction treatment of the samples. In addition, the elemental composition has a strong effect on the selectivity. An optimum composition in terms of selectivity is attained for a narrow range of $60-70 \mathrm{~mol} \% \mathrm{Cu}$ for the constant $\mathrm{pH}$ samples. This investigation of the selectivity of binary catalysts in methanol steam reforming supplements previous studies on the catalytic performance for binary $\mathrm{Cu} / \mathrm{Zn}$ catalysts with different $\mathrm{Cu} / \mathrm{Zn}$ ratios $(26,13)$. The most stable sample is C70/30 'wet' as it shows only small variation in conversion and selectivity.

It is clear from Table 2 that there is no straightforward correlation of the production rate with the $\mathrm{Cu}$ surface area over the entire compositional range of the samples. In addition, it is found that although in most cases the 'wet' reduction mode results in a higher copper surface area an enhanced production rate is not observed for those samples (e. g. samples D40/60, D50/50, and C70/30). In addition, in all cases, the D-series samples exhibit a higher activity for a given copper surface area than the C-series samples.

In order to relate differences in performance of the catalyst to effects originating from preparation parameters, the composition, and the reduction conditions, the production rate is normalized to the $\mathrm{Cu}$ metal surface area estimated from the copper XRD crystallite size. The initial TOF for $\mathrm{H}_{2}$ is a function of the $\mathrm{ZnO}$-content (see Fig. 3). Comparing the TOF values (ranging from 0.2 to 1.3 ) to other studies which employ similar reaction conditions although with equimolar $\mathrm{MeOH} / \mathrm{H}_{2} \mathrm{O}$ ratio it is found that they are of the same order of magnitude $(26,13)$. However, highest TOF values are reported by Shen et al. (26) for the pure copper sample whereas in our study the catalyst with $60 \mathrm{~mol} \% \mathrm{Cu}$ exhibits the highest intrinsic activity irrespective of preparation or reduction conditions. The 
TOF values for catalysts with $\mathrm{ZnO}$-contents higher than 40 mol-\% $\mathrm{Zn}$ do not show the nearly linear increase in TOF with increasing $\mathrm{Zn}$ content seen in the samples with less $\mathrm{Zn}$. For concentration $>40 \mathrm{~mol} \% \mathrm{Zn}$ the $\mathrm{TOF}$ is independent on the $\mathrm{Cu}$ surface area and the values do not differ much as a function of preparation and reduction mode. Furthermore, catalysts prepared at decreasing $p H$ displayed a higher overall TOF than samples prepared at constant $p H$. This indicates that the precipitation $p H$ affects the activity of the copper in the final catalyst. The influence of the $p H$ during preparation is only seemingly in contrast to the behavior of the selectivity, which showed no dependence on the $p H$ during preparation, because for the determination of the TOF for $\mathrm{H}_{2}$ all reactions affording hydrogen were taken into account. In addition, 'wet' reduction leads to higher TOF-values for the decreasing $p H$ sample batch whereas 'dry' reduced constant $\mathrm{pH}$ samples exhibit a slightly higher TOF-values. The significant deviations from a constant TOF as a function of the composition implies that the copper surface area alone cannot adequately account for the differences in intrinsic activity. The catalyst D60/40 is exceptional as the activity of a copper surface atom can be twice as high for a given elemental composition than that for the sample C60/40 indicating the influence of preparation parameters on the catalytic activity as a function of the $\mathrm{pH}$ during preparation (i.e. increased TOF) (Fig. 3).

The absence of a linear relationship between the copper surface area and the methanolsteam reforming activity provides additional evidence that the methanol steam reforming reaction is "structure sensitive". This is in contrast to results by Shen et al. (26) who proposed that the production rate is associated with the surface of metallic $\mathrm{Cu}$. A "structure-sensitivity" was reported by Hadden et al (45) for the water-gas shift reaction. They have shown that the specific activity is not directly correlated to the $\mathrm{Cu}$ metal surface area and concluded that preparation parameters determine to a large extent the activity for a given $\mathrm{Cu}$ surface area. In a recent publication by Peppley et al. a kinetic model for methanol-steam reforming is presented (6). It was found that the methanol steam reforming reaction and the methanol decomposition to $\mathrm{CO}$ and hydrogen proceed on different active sites, although the rate-determining step (dehydrogenation of absorbed methoxy groups) is the same in both cases. Furthermore, it was shown that the active site responsible for the methanol steam reforming reaction is similar to the one responsible for the water-gas shift reaction. This type of sites is thought to be formed in situ and incorporates the presence of $\mathrm{Cu}^{2+}$ aggregates stabilized by hydroxyl and carbonate groups (46).

The present work indicates that an additional microstructural parameter different from the $\mathrm{Cu}$ surface area is operative. This becomes more apparent in the catalytic experiments after oxidation/re-reduction cycles. In situ XRD afforded an increase in crystallite size after oxygen addition cycle accompanied by an increase in conversion of methanol and selectivity to $\mathrm{CO}_{2}$ (Table 3).
The increase in crystallite size can reach up to $~ 90 \%$ (from $70 \AA$ to $120 \AA$ for the sample C70/30). The origin of this pronounced increase in $\mathrm{Cu}$ crystallite size after each oxidation cycle can be related to a structural rearrangement during oxidation and re-reduction (Fig. 4). Although the increase in $\mathrm{Cu}$ particle size results in a loss of $\mathrm{Cu}$ surface area, higher conversions and selectivities are observed (Table 3) after oxidation cycles. Combining the activity data for the oxidation cycles shown in Fig. 5 (sample C60/40) with the $\mathrm{Cu}$ crystallite size determined by in situ $\mathrm{XRD}$ an increase of the TOF as a function of oxidation cycle can be measured. After the first cycle the TOF increases from 1.1 to 1.5 and after the second cycle the TOF reaches $1.6 \mathrm{~s}^{-1}$. Again, these observations are in contrast to the simplified correlation of the catalytic activity with the $\mathrm{Cu}$ surface area, and, hence, the crystallite size (26). A lattice parameter determination by in situ XRD yielded a continuous increase of the copper lattice parameter and the $\mathrm{ZnO}$ lattice parameters $a$ and $c$ under methanol steam reforming conditions and with each oxygen addition cycle (Fig. 6). The evolution of the lattice parameters may originate from the influence of the $\mathrm{Cu} / \mathrm{ZnO}$ interface which may increase after each oxygen addition cycle, increasing the effect of the misfit of the two lattices (see below, XAS discussion). Using the Voigt method (47) it is found that in addition to size effects the broadening of the $\mathrm{Cu}$ (111) diffraction line is also caused by microstrain in the $\mathrm{Cu}$ bulk. For the sample D60/40 a Cu crystallite size of $90 \AA$ was determined while the extent of strain amounted to $0.7 \%$. After oxidative treatments and growth of the copper crystallites (increase in size to $102 \AA$ ) the strain contribution to the peak broadening $(0.7 \%)$ was unchanged, indicating that there was no accompanying annealing of defects.

Apparently, the re-oxidation experiments in the $\mathrm{XRD}$ cell show that a high $\mathrm{Cu}$ surface area is a prerequisite for an active $\mathrm{Cu} / \mathrm{ZnO}$ catalyst. However, additional microstructural parameters need to be considered to account for the activity and selectivity observed. Further evidence for bulk structural changes under reaction conditions were gained from the in-situ XAFS experiments.

\section{II.) In situ XAFS}

\section{Activation of the $\mathrm{CuO} / \mathrm{ZnO}$ catalysts - TPR}

Time-resolved XANES experiments at the $\mathrm{Cu} \mathrm{K}$ edge indicate that $\mathrm{Cu}(\mathrm{I})$ oxide is an intermediate of the reduction of the $\mathrm{CuO} / \mathrm{ZnO}$ systems studied (Fig. 7 (a)). In addition, these experiments afforded the evolution of the three phases $\mathrm{CuO}, \mathrm{Cu}$, and $\mathrm{Cu}(\mathrm{I})$ oxide during temperatureprogrammed reduction of $\mathrm{CuO} / \mathrm{ZnO}$ (Fig. 7) not accessible by conventional TPR studies. Previously, features in the TPR spectra of $\mathrm{CuO} / \mathrm{ZnO}$ system were attributed to different degrees of dispersion of the $\mathrm{CuO}$ without taking possible intermediates during the reduction processes into account (12). Compared to in situ XRD results where the detection of copper metal requires a certain minimum crystallite size which in TPR causing a delay in the appearance of copper metal after detection of the evolution 
of water, in situ XAS can afford complementary information on the early stage of reduction. Apparently, the reducibility of the $\mathrm{CuO} / \mathrm{ZnO}$ systems $(\mathrm{Cu}$ nuclei formation during reduction) depends not only on the $\mathrm{Cu} / \mathrm{Zn}$ ratio in the catalyst as has been reported before (12) but also on the preparation conditions of the hydroxycarbonate precursor. This supports previous findings on the influence of the preparation method on the reduction process by Fierro et al. (14) and Himelfarb et al. (17).

\section{Steam reforming of methanol}

Time-resolved in situ XAFS measurement were performed to correlate different copper phases with catalytic activity during oxygen addition cycles to the methanol steam reforming feed (Fig. 8, Fig. 9). The changes in $\mathrm{Cu}$ phase composition and the evolution of the gas phase for one oxygen addition cycle are shown in Fig. 10. After the addition of oxygen, $\mathrm{Cu}$ (I) and $\mathrm{Cu}(\mathrm{II})$ oxide constitute the major copper bulk phases. In regime III (Fig. 10) copper metal is formed again and its formation is accompanied by an increasing hydrogen production but no $\mathrm{CO}$ or methyl formate is formed in this period. This could imply that the methanol dehydrogenation reaction is favored over $\mathrm{Cu}$ in a positive oxidation state. The formation of $\mathrm{CO}$ and methyl formate (ppm levels) originating from methanol steam reforming is observed only after the concentration of metallic copper in the bulk phase exceeds $80 \mathrm{w}-\%$ (regime III to I in Fig. 10). The maximum concentration of $\mathrm{CO}$ and methyl formate (1000 ppm) coincides with the complete reduction of the copper phases to $\mathrm{Cu}$ metal. Our observation of both methyl formate $\left(\mathrm{HCOOCH}_{3}\right)$ and $\mathrm{CO}$ in regime I (Fig. 10) supports the sequence of reaction steps involving dehydrogenation and methylformate formation. During subsequent methanol steam reforming, the CO level is continuously decreasing whereas the concentration of methyl formate remains constant. In this regime (I in Fig. 10) methanol steam reforming appears to be the predominant reaction. It can be concluded that the changes of bulk phase and gaseous product composition observed during oxygen addition cycles permit one to distinguish between different active states of copper operative in the $\mathrm{Cu} / \mathrm{ZnO}$ system. The results support previous assumption based on kinetic analysis of surface reactions that parallel reaction might occur on different active copper phases during methanof steam reforming $(8,6)$. Interestingly, the oxidation and reduction curves of $\mathrm{Cu}$ metal in the upper graph in Fig. 10 exhibit in both cases a similar sigmoidal shape for both solid state processes indicating similar rate determining steps and reaction rates.

Implication of microstructural changes of $\mathrm{Cu}$ and $\mathrm{ZnO}$ on the catalytic activity

The existence of copper suboxides in the bulk during methanol steam reforming can be excluded within the detection limits of XAFS $\left(\sim 1 \mathrm{w}_{-} \%\right)$ in the XANES region. Furthermore, for the $\mathrm{Cu}$ edge EXAFS no $\mathrm{Cu}-\mathrm{O}$ shells were distinguishable after applying the difference file technique. Nevertheless, the formation of mixed valence copper suboxides at the catalysts surface cannot be excluded. Surface oxygen atoms on copper (under methanol oxidation conditions) which are different from oxygen in well-defined copper oxides have recently been reported by Knop-Gericke et al. using surface sensitive in situ XAS $(48,49)$.

In recent publications $(50,51)$ the dynamics of the $\mathrm{Cu} / \mathrm{ZnO}$ system were ascribed to changes in the morphology of the $\mathrm{Cu}$ surface. Clausen et al. (50) observed using EXAFS dynamical changes of the system upon changing the reduction potential in the gaseous environment and ascribed them to changes in the surface morphology (wetting/non-wetting phenomena). They showed that by taking changes in surface area and morphology (i. e. formation of $\mathrm{Cu}(110)$ and $\mathrm{Cu}(100)$ surfaces with higher activity) into account a "dynamic" microkinetic model for the methanol synthesis reaction under different gas atmospheres could be deduced. Sakakini et al. (51) reported on surface morphology changes of a supported $\mathrm{Cu} / \mathrm{ZnO} / \mathrm{Al}_{2} \mathrm{O}_{3}$ catalyst using IR spectra of adsorbed CO. The copper surface termination and the activity for $\mathrm{CO}_{2}$ decomposition showed a dependence on the reductive treatment after previous oxidation.

In the work presented here microstructural changes of $\mathrm{Cu}$ and $\mathrm{ZnO}$ upon oxygen addition cycles are correlated to methanol steam reforming activity. The EXAFS refinements to the experimental $\mathrm{Cu}$ and $\mathrm{ZnO}$ ?(k) gave ample evidence of the bulk structural interaction of both phases leading to the following structural changes (Fig.11, Fig. 15). The unusual high Debye-Waller factor of the fifth copper shell indicates a medium range structural disorder of the $\mathrm{Cu} / \mathrm{ZnO}$ at room temperature (Fig.12). This structural disorder may be caused by interaction at the $\mathrm{Cu} / \mathrm{ZnO}$ interface assuming an expansion of the $\mathrm{Cu}$ lattice at the interface. An epitaxial orientation of the $\mathrm{Cu}$ (111) surface to the $\mathrm{ZnO}$ (001) surface has been found to exist in the $\mathrm{Cu} / \mathrm{ZnO}$ system (52). Upon increasing the temperature to $523 \mathrm{~K}$ the copper lattice will expand more than the $\mathrm{ZnO}$ lattice because of the difference in the linear thermal expansion coefficients, ?, of $\mathrm{Cu}\left(?_{\mathrm{Cu}}, 500 \mathrm{~K}=17.4 \cdot 10^{-6} \mathrm{~K}^{-}\right.$ ${ }^{1}(53)$ and $\mathrm{ZnO}$ (perpendicular to the $c$-axis: ? $\mathrm{ZnO}, 500 \mathrm{~K}=$ $\left.71.5 \cdot 10^{-7} \mathrm{~K}^{-1}(54)\right)$. At elevated temperature the thermal expansion of $\mathrm{Cu}$ results in a partial release of the lattice mismatch at the interface and, thus, in a reduction of structural disorder as indicated by the decreased or constant DW factors of the fifth $\mathrm{Cu}$ shell (Fig. 12).

In situ EXAFS measurements during oxygen addition cycles under methanol steam reforming conditions gave further evidence of microstructural changes in the $\mathrm{Cu} / \mathrm{ZnO}$ samples (Fig. 14). The Cu Debye-Waller factors indicated that the medium range disorder for copper particles increased with each oxidation/re-reduction cycle (see Fig. 13) while the copper crystallite size as detected by XRD increases after each oxygen addition cycle. After oxidation/re-reduction cycles the increase in medium range 
disorder is accompanied by a depletion of $\mathrm{Zn}$ incorporated in the $\mathrm{Cu}$ clusters (Fig. 14 and Fig.15) ( 4.3 mol\% for sample $\mathrm{C} 70 / 30$ to $1.3 \mathrm{~mol} \%$ after two cycles). The observed lattice expansion of $<0.02 \AA$ (Fig. 6) is below the limits for a reliable distance determination by EXAFS. The $\mathrm{Zn}$ atoms dissolved in $\mathrm{Cu}$ stem from the structural arrangement in the hydroxycarbonate precursor structure and maintain their position in the $\mathrm{Cu}$-matrix under the mild calcination $(600 \mathrm{~K})$ and reduction conditions $\left(5 \mathrm{vol} \% \mathrm{H}_{2}\right.$ at $523 \mathrm{~K}$ ) used (39). Apparently, the amount of $\mathrm{Zn}$ dissolved in the copper clusters depends not only on the $\mathrm{Cu} / \mathrm{Zn}$ ratio of the catalyst but also on the structure of the hydroxycarbonate precursor as indicated by the lower $\mathrm{Zn}$ concentration for $\mathrm{Cu}$ in the more Zn-rich C60/40 sample as compared to the $\mathrm{C} 70 / 30$ sample. The incorporation of $\mathrm{Zn}$ in $\mathrm{Cu}$ can be regarded as a modification of the copper surface leading to a modified reactivity as previously discussed by Nakamura et al. (55) for $\mathrm{Cu} / \mathrm{ZnO}$ catalysts in methanol synthesis.

Moreover, substantial incorporation of $\mathrm{Cu}$ into the $\mathrm{ZnO}$ matrix ( $>1 \%$ ) for $\mathrm{Zn}$-rich catalysts as found by Klier et al. (56) can be excluded on the basis of their EXAFS results.

Taking this experimental evidence into account it seems reasonable to assume that the enhanced activity after oxidative treatment for methanol steam reforming is closely related to disorder and strain in $\mathrm{Cu}$ particles in an analogous manner as it was found for $\mathrm{Cu} / \mathrm{ZnO}$ catalysts in methanol synthesis. Regarding the role of defects in copper we have recently reported (39) on the implication of the $\mathrm{Cu}$ lattice strain of copper clusters in the crystallite size regime $50-200 \AA$ on the methanol synthesis activity. It is suggested that the microstrain modifies the $\mathrm{Cu}$ surface and thus contributes to an enhanced methanol synthesis activity (39). The structural defects of $\mathrm{Cu}$ were ascribed to the dissolution of $\mathrm{Zn}$ in $\mathrm{Cu}$, incomplete reduction or epitaxial orientation of $\mathrm{Cu}$ and $\mathrm{ZnO}$. This concept seems to be transferable to the active copper phase in the methanol steam reforming reaction. Modified $\mathrm{Cu}$ surfaces were found to have a promotional effect on the methanol synthesis activity and it appears from our data that for methanol steam reforming a similar structural disorder of the copper bulk also results in a higher activity and selectivity. This is clearly shown by the increase of the TOF after each oxidation cycle indicating a more active copper surface.

\section{Model of microstructural changes of $\mathrm{Cu}$ and $\mathrm{ZnO}$}

The microstructural modifications detected by XAFS and XRD during oxygen addition cycles under working conditions can be summarized by the schematic model given in Fig. 16. The model depicts the structural rearrangement of $\mathrm{Cu}$ on $\mathrm{ZnO}$ for a freshly reduced catalyst (a) and a more active catalyst (b) after oxidation and subsequent reduction. For the freshly reduced catalyst the small copper particles are in interfacial contact with the supporting $\mathrm{ZnO}$, possibly exhibiting an epitaxial orientation. The $\mathrm{Cu}$ crystallite size is only slightly lower than that of $\mathrm{ZnO}$ and the copper particles exhibit some structural disorder which may be caused by microstrain originating at the $\mathrm{Cu} / \mathrm{ZnO}$ interface. Furthermore, a considerable amount of $\mathrm{Zn}$ (up to $4.3 \mathrm{~mol}-\%$ ) is incorporated into the $\mathrm{Cu}$ clusters, occupying $\mathrm{Cu}$ lattice sites and forming a solid solution of $\mathrm{Zn}$ in $\mathrm{Cu}$. After oxidation and subsequent reduction (Fig. 23b) the crystallite sizes of $\mathrm{Cu}$ and $\mathrm{ZnO}$ increase, resulting in a reduced surface area which may also be accompanied by an increased interface area between $\mathrm{Cu}$ and $\mathrm{ZnO}$. With the observed growth in crystallite size there is a decrease in the concentration of $\mathrm{Zn}$ in the $\mathrm{Cu}$, and an increase in structural disorder in the $\mathrm{Cu}$ particles as indicated by the increasing $\mathrm{Cu}$ Debye-Waller factors for higher $\mathrm{Cu}-\mathrm{Cu}$ shells. The partial segregation of $\mathrm{Zn}$ atoms out of the $\mathrm{Cu}$ latice seems to increase interface interaction between $\mathrm{Cu}$ and $\mathrm{ZnO}$. It is speculated that the $\mathrm{Zn}$ atoms incorporated in the $\mathrm{Cu}$ particles diminishes the effect of the $\mathrm{Cu} / \mathrm{ZnO}$ interface on the copper particles and, therefore, the microstrain is not transmitted across the entire copper matrix, and does not modify the copper surface. Hence, after oxidation and re-reduction larger domains of distorted and strained copper are formed on the $\mathrm{ZnO}$ support. Much more than an inert support, $\mathrm{ZnO}$ appears to be a crucial component in modifying the microstructure (e.g. interface interaction, $\mathrm{Zn}$ incorporation in $\mathrm{Cu}$ particles), and thus the activity of the copper.

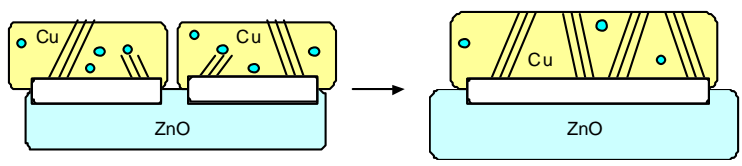

Fig. 16 Proposed schematic model for copper particles on a $\mathrm{ZnO}$ support after initial reduction (a) and after repeated oxygen addition cycles under methanol steam reforming conditions (b). The microstructural modifications upon oxidative treatment result in an increasing crystallite size and a larger interface area between $\mathrm{Cu}$ and $\mathrm{ZnO}$. Moreover, the $\mathrm{Cu}$ clusters are depleted of $\mathrm{Zn}$ accompanied with larger domains of structural disorder (e.g. strain) in $\mathrm{Cu}$ (parallel lines).

With respect to model systems for nanosized $\mathrm{Cu} / \mathrm{ZnO}$ catalysts, in light of our findings, a suitable model system needs to account for the strong support influence of $\mathrm{ZnO}$ on $\mathrm{Cu}$ and for $\mathrm{Zn}$ incorporated in the copper bulk.

\section{Conclusion}

Evolution of bulk phases of $\mathrm{Cu} / \mathrm{ZnO}$ catalysts under reduction conditions was monitored by in situ XRD and XAFS revealing the following:

(a1) From time-resolved in situ XAFS experiments at the $\mathrm{Cu} \mathrm{K}$ edge, $\mathrm{Cu}(\mathrm{I})$ oxide was found to be an intermediate of the reduction of $\mathrm{CuO} / \mathrm{ZnO}$ according to a two step reduction process $(\mathrm{CuO} \& \mathrm{Cu}(\mathrm{I})$ oxide $\mathrm{Cu}$ ).

(a2) $\mathrm{CuO} / \mathrm{ZnO}$ precursors which were less easily reduced (high reduction onset temperature) afforded $\mathrm{Cu}$ crystallites that are more selective in steam 
reforming of methanol. The use of 'wet' reduction conditions, also resulting in a shift to higher onset of reduction temperatures, also produces catalysts exhibiting a higher selectivity.

Structural and catalytic properties were monitored during methanol steam reforming reaction by in situ XRD and XAFS and the following conclusions were drawn:

(b1) Completely reduced $\mathrm{Cu}$ clusters on $\mathrm{ZnO}$ constitute the active bulk phase for methanol steam reforming with no further oxidized $\mathrm{Cu}$ species detectable (< $1 \%)$.

(b2) Upon repeated oxygen addition cycles, the catalyst exhibited an enhanced activity (i.e. increased TOF) and selectivity. It was shown by XRD and EXAFS that repeated oxygen addition cycles lead to a crystallite growth of both the copper and zinc oxide crystallites accompanied by a segregation of $\mathrm{Zn}$ out of the $\mathrm{Cu}$ bulk. However, the Debye-Waller factors for higher $\mathrm{Cu}-\mathrm{Cu}$ shells suggest an increasing structural disorder (e.g. strain). The strain is thought to originate at the $\mathrm{Cu} / \mathrm{ZnO}$ interface.

(b3) $\quad \mathrm{ZnO}$ is not just a support but an integral part of the active $\mathrm{Cu} / \mathrm{ZnO}$ catalyst. The bulk structure and, hence, the catalytically active surface is modified by the intimate $\mathrm{Cu} / \mathrm{ZnO}$ interface.

(b4) The microstructural changes of copper and zinc correlate with increased methanol steam reforming activity and selectivity. This indicates that although a high $\mathrm{Cu}$ surface area is a prerequisite for catalytic activity it does not account for the observed changes in activity and selectivity alone without taking bulk structural changes into account. We conclude that similar to methanol synthesis the enhanced activity in $\mathrm{Cu} / \mathrm{ZnO}$ catalysts after oxidative treatment for methanol steam reforming is closely related to an increased disorder and microstrain in $\mathrm{Cu}$ particles.

In this study it was shown that for "real" $\mathrm{Cu} / \mathrm{ZnO}$ catalysts solid state transformation and interaction of the $\mathrm{Cu}$ and $\mathrm{ZnO}$ phases have a pronounced influence on the catalytic activity. Therefore, "ideal" $\mathrm{Cu}$ clusters fail to describe the structural imperfections observed and, hence, cannot be expected to be suitable model systems. Apparently, a suitable model system needs to account for both strong $\mathrm{Cu} / \mathrm{ZnO}$ interface interactions and $\mathrm{Zn}$ incorporated in the copper bulk.

\section{Acknowledgment}

The authors are grateful to Prof. Robert Schlögl for valuable discussions and continuous support. T.R. thanks the Deutsche Forschungsgemeinschaft "DFG" for financial support (Habilitationsstipendium). We acknowledge the Hamburger Synchrotron Radiation Laboratory, HASYLAB, for providing beamtime for this work.

\section{References}

1. Takahashi, K., Takezawa, N., and Kobayashi, H., Appl. Cat. 2, 363, (1982).

2. Amphlett, J.C., Evans, M.J., Mann, R.F., and Weir, R.D., Can. J. Chem. Eng. 63, 605, (1985).

3. Peters, R., Dusterwald H.G., and Hohlein, B., J. Power Sources 86, 507 (2000).

4. Amphlett, J.C., Creber, K.A.M., Davies, J.M., Mann, R.F., Peppley, B.A., and Stokes, D.M., Int J. Hydrogen Energy 19(2), 131, (1994).

5. Breen, J.P., Meunier, F.C., and Ross, J.R., Chem. Commun., 2247 (1999).

Peppley, B.A., Amphlett, J.C., Kearns, L.M., and Mann, R.F., Appl. Catal. A. 179, 21 (1999).

Jiang, C.J., Trimm, D.L., and Wainwright, M.S., Appl. Cat. A 93, 245 (1993).

Peppley, B.A., Amphlett, J.C., Kearns, L.M., and Mann, R.F., Appl. Catal. A. 179, 31 (1999).

Clausen, B.S., Topsøe, H., and Frahm, R., Adv. Catal. 42, 315 (1998).

Clausen, B.S., Steffensen, G., Fabius, B., Villadsen, J., Feidenshans'l, R., and Topsøe, H., J. Catal. 132, 524 (1991).

Skrzypek, J., Sloczynski, J., and Ledakowicz, S., "Methanol synthesis.”, Polish Scientific Publishers, Warsaw, 1994.

Fierro, G., Lo Jacono, M., Inversi, M., Porta, P., Lavecchia, R., and Cioci, F., J. Catal. 148, 709 (1994).

Breen, J.P., and Ross, J.R.H., Cat. Today 51, 521, (1999).

Fierro, G., Lo Jacono, M., Inversi, M., Porta, P., Cioci, F., and Lavecchia, R., Appl. Catal. A 137, 327 (1996).

Ruggeri, O., Trifirò, F., and Va ccari, A., J. Solid State Chem. 42, 120 (1982).

Plewa, J., and Skrzypek, J., Chem. Eng. Sci. 44, 2817 (1989).

Himelfarb, P.B., Wawner Jr., F. E., Bieser Jr., A., and Vines, S. N., J. Catal. 83, 469 (1983).

Vong, M.S.W., Sermon, P.A., and Grant, K., Cat. Let., 4, 15, (1990).

Porta, P., Dragone, R., Lo Jacono, M., and Minelli, G., and Moretti, G., Solid State Ionics 32/33, 1019 (1989).

Als-Nielsen, J., Grübel, G., and Clausen, B.S., Nucl. Instr. and Meth. in Phys. Res. B, 97, 522 (1995).

Reitz, T.L., Lee, P.L., Czaplewski, K.F., Lang, J.C., Poop, K.E., and Kung, H.H., J. Catal. 199, 193, (2001).

Fernández-García, M., Rodríguez-Ramos, I., Ferreira-Aparicio, P., and Guerro-Ruiz, A., J. Catal. 178, 253, (1998).

Grunwaldt, J.-D., Molenbroek, A. M., Topsøe, N.-Y., Topsøe, H., and Clausen, B.S., J. Catal. 194, 452 (2000).

Idem, R.O., and Bakhshi, N.N., Can. J. Chem. Eng. 74, 288 (1996).

Klier, K., Adv. Catal. 31, 243 (1982).

Shen, G.C., Fujita, S., Matsumoto, S., and Takezawa, N., J. Mol. Cat. A. 124, 123 (1997)

Bems, B., Günter, M., Schur, M., and Schlögl, R., in preparation. 
Ressler, T., Jentoft, R.E., Wienold, J., Günter, M.M., and Timpe, O., J. Phys. Chem., 104, 6360 (2000)

Snyder, R.L., in "The Rietveld Method" (R.A Young, Ed.), IUCr, Monographs on Crystallography 5, Oxford University Press (1993). PowderCell v2.2, W. Kraus, and G. Nolze, Bundesanstalt für Materialprüfung, Berlin (1999).

Designed by M. Hagelstein, T. Neisius, et al., ESRF, France, in a collaborative

effort with the Fritz-Haber-Institut, Berlin, Germany

Ressler, T., J. Synch. Rad. 5, 118 (1998).

Ressler, T., Wong, J., Roos, J., and Smith, I.L., Environ. Science Tech. 34, 950 (2000).

Rehr, J.J., Booth, C.H, Bridges, F., and Zabinsky, S.I., Phys. Rev. B 49, 12347 (1994).

Rehr, J.J., Albers, R.C., and Zabinsky, S.I., Phys. Rev. Lett. 69, 3397 (1992).

Bunker, G., Nucl. Instrum. Methods 207, 437 (1983).

Ressler, T., Brock, S.L., Wong, J., and Suib, S.L., J. Phys. Chem. B 103, 6407 (1999).

Anderson, J.R., and Pratt, K.C., "Introduction to characterization and testing of catalysts", Academic Press, New York, 1985.

Günter, M.M., Ressler, T., Bems, B., Büscher, C., Genger, T., Hinrichsen, O., Muhler, M., and Schlögl, R., Cat. Let. 71, 1-2 (2001) .

Clausen, B.S., and Nørskov, J.K., Topics in Catalysis 10, 221 (2000).

Chinchen, G.C., Denny, P.J., Jennings, J.R., Spencer, M.S., and Waugh, K.C., Appl. Cat. 36, 1 (1988).

Spencer, M.S., Topics in Catalysis 8, 259 (1999).

Gonzalez, J.C., Gonzalez, M.G., Laborde, M.A., and Moreno, N., Appl. Catal. 20, 3 (1986)

Wimmer, O.J., Arnoldy, P., and Moulijn, J.A., J. Phys. Chem. 90, 1331 (1986).

Hadden, R.A., Lambert, P.J. and, Ranson, C., Appl. Catal. 122, L1 (1995).

Andreev, A.A., Kalchev, M.G., Christov, G.D., and Andreeva, D.C., Kinet. Katal. 36, 828 (1995).

Langford, J.I., J. Appl. Crystallogr. 11, 10 (1978).

Knop-Gericke, A., Hävecker, M., Schedel-Niedrig, T., and Schlögl. R., Cat. Lett. 66, 215 (2000).

Knop-Gericke, A., Hävecker, M., Schedel-Niedrig, T., and Schlögl. R., Topics in Catalysis. 10, 187 (2000).

Ovesen, C.V., Clausen, B.S., Schiøtz, P., Stoltze, P., Topsøe, H., and Nørskov, J.K., J. Catal. 168, 133 (1997).

Sakakini, B.H., Tabatabaei, Watson, M.J., and Waugh, K.C., J. Mol. Catal. A. 162, 297 (2000).

Herman, R.G., Simmons, G.W., and Klier, K., Proc. of the $7^{\text {th }}$ Int. Cong. on Cat., 475, (1980).

Uffelmann. L., Phil. Mag. 7, 633 (1930).

Ibach, H., Phys. Status Solidi 33, 257 (1969).

Nakamura, J., Nakamura, I., Uchijima, T., Wantanabe, T., and Fujitani, T., Stud. Surf. Sci. Catal., 101, 1389 (1996)

Dominiquez, J.M., Simmons, G.W., and Klier, K., J. Mol. Catal. 20, 369 (1983). 